\title{
A Dualidade de crises dos Estados Unidos da América: reflexão sobre oportunidades, possibilidades e o papel dos BRICS para uma nova ordem mundial
}

The duality of crises of the United States of America: reflection on opportunities, possibilities and the role of the BRICS for a new world order

La dualité de crises des États-Unis d'Amérique: réflexion sur possibilités et le rôle des BRIC pour una nouvelle ordre mondiale

La dualidad de la crisis de los Estados Unidos de América: reflexión sobre oportunidades, posibilidades y el papel de los BRICS en una nueva orden mundial

Nelson Laura Mabucanhane

\section{OpenEdition}

\section{Journals}

Edição electrónica

URL: http://journals.openedition.org/espacoeconomia/1382

DOI: $10.4000 /$ espacoeconomia. 1382

ISSN: 2317-7837

Editora

Núcleo de Pesquisa Espaço \& Economia

\section{Refêrencia eletrónica}

Nelson Laura Mabucanhane, «A Dualidade de crises dos Estados Unidos da América: reflexão sobre oportunidades, possibilidades e o papel dos BRICS para uma nova ordem mundial », Espaço e Economia [Online], 5 | 2014, posto online no dia 29 dezembro 2014, consultado o 10 junho 2020. URL: http://journals.openedition.org/espacoeconomia/1382 ; DOI : https://doi.org/10.4000/ espacoeconomia.1382

Este documento foi criado de forma automática no dia 10 junho 2020.

(C) NUPEE 


\section{A Dualidade de crises dos Estados Unidos da América: reflexão sobre oportunidades, possibilidades e o papel dos BRICS para uma nova ordem mundial}

The duality of crises of the United States of America: reflection on opportunities, possibilities and the role of the BRICS for a new world order

La dualité de crises des États-Unis d'Amérique: réflexion sur possibilités et le rôle des BRIC pour una nouvelle ordre mondiale La dualidad de la crisis de los Estados Unidos de América: reflexión sobre oportunidades, posibilidades y el papel de los BRICS en una nueva orden mundial Nelson Laura Mabucanhane

NOTA DO AUTOR

O texto foi produzido para orientar os debates do Seminário de Pesquisa do dia 23.09.2014 no PPFH. Agradeço a Coordenação de Aperfeiçoamento de Pessoal de Nível Superior (CAPES) pela bolsa concedida e ao meu orientador Floriano Godinho de Oliveira por todo apoio que tem dado.

\section{Introdução}

Desde que o Grupo Econômico Goldman Sachs cunhou o "termo" BRICs ${ }^{1}$, em 2001, para fazer referência aos principais mercados emergentes (naquele momento, Brasil, Rússia, Índia e China e, a partir de 2011, também a África do Sul), a literatura especializada e/ 
ou interessada em economia política internacional tem publicado inúmeros estudos, como é o caso, por exemplo, dos trabalhos de Lima e Hirst (2009), Chellaney (2014), Zhebit et al (2010), Gaidar (2009), Harvey (2013), Hurrell (2009), Velloso et al (2009), Qian (2014), Dos Santos (2002). Dois fatores fundamentais têm interessado estes e outros estudos: i) o espetacular crescimento econômico dos BRICS, em particular, e do Sul em geral, e; ii) a dualidade de crises dos Estados Unidos da América (EUA) - crise econômica desde 2007 e crise política junto aos tradicionais aliados, cujo ápice ganhou maior relevo em 2003 com a invasão ao Iraque, sendo este também um dos focos literários. Para além da literatura tardia sobre a crise (a que se refere ao estudo da crise como, principalmente, crise econômica norte-americana e ao crescimento dos BRICS), a vitória do capitalismo sobre o socialismo, simbolizada pela queda do muro de Berlim, gerou uma série de estudos desde 1990, cujo enfoque é o imperialismo norte-americano, sobretudo após o ataque ao Iraque, por exemplo, Boron (2002), Kagarlitsky (2005), Wallerstein (2002), Harvey (2004), Klare (2004), Goldman (2007), Dos Santos (2004) e (1993). Se para Fukuyama (1992) o acontecimento histórico de Berlim exprimia a vitória do capitalismo, para Wallerstein (2002) tal fato representa o colapso do liberalismo e a entrada ao período pós-liberalismo.

2 Desde a primeira década dos anos 2000, a busca de caminhos para equilibrar o poder econômico e político-militar dos EUA constitui o problema central de muitos estudos. Esse é um interesse que, embora se reconhecendo que o capitalismo se regenera através de crises cíclicas, ganhou maior relevo com a emergência dos BRICS. Um dos elementos fundamentais que favorece tal conveniência é a ocorrência quase que paralela entre a crise norte-americana e o crescimento inédito dos BRICS. É nesta simultaneidade que surgem debates acesos e muitas vezes contraditórios entre os que defendem a crise transição para uma nova ordem mundial através dos BRICS e os que resguardam a idéia de crise-restauração da hegemonia da economia norte-americana.

3 Nesse período de maior agonia, muitos estudos levantam uma infinidade de questões, como por exemplo: i) Até que ponto a crise econômica mundial é uma oportunidade para uma nova ordem internacional? ii) Dada a desconfiança político-militar entre os BRICS, como explicar que as boas relações econômicas e o espetacular crescimento econômico possam, efetivamente, representar uma oportunidade para uma nova ordem mundial? iii) Que tipo de mudanças fundamentais precisamos no novo sistema mundial? iv) Como é que as fragilidades internas dos BRICS (diversidade cultural, histórica, política e econômica) podem se traduzir em uma possibilidade para uma nova ordem mundial? v) Que segurança a humanidade tem de que a nova ordem mundial através dos BRICS será melhor, considerando-se o dilema da segurança e experiências do passado? vi) Até que ponto a ordem dos BRICS não é uma extensão da ordem neoliberal?

4 Estas e outras questões representam, não só a zona de penumbra que enferma a economia política internacional, como, também, as perguntas-chave que orientaram este artigo. $O$ argumento principal que o referencia é de que a nova ordem mundial não é produto apenas da crise econômica dos EUA, mas esta é uma oportunidade para mudanças estruturais e globais, considerando-se que o crescimento econômico dos BRICS gera possibilidades que lhes conferem maior protagonismo no processo transitório para uma nova ordem mundial.

5 Assim, com o objetivo de discutir as oportunidades e possibilidades para uma nova ordem mundial através dos BRICS face à crise econômica mundial dos EUA, foi 
elaborado o presente artigo. Especificamente, o artigo pretende: i) refletir sobre a crise econômica norte-americana, para depois, ii) examinar as oportunidades e possibilidades da economia política dos BRICS para instaurar uma nova ordem mundial. Quanto à organização, o texto está dividido em três partes fundamentais, para além da presente introdução e das considerações finais. A primeira parte apresenta uma breve contextualização do binômio Estados Unidos da América (EUA) versus BRICS. $O$ enfoque desta parte é a trajetória norte-americana após a Segunda Guerra Mundial até se tornar em superpotência capaz de ditar as regras da economia política internacionais. A segunda parte faz uma análise sucinta da dualidade de crises norte-americanas (econômica e política junto aos tradicionais aliados). A pretensão desta segunda parte é perceber até que ponto a crise econômica norte-americana é tão profunda que se torne capaz de abrir espaço para uma crise transição a favor dos BRICS. A terceira e última parte, examina as oportunidades e possibilidades de uma Nova Ordem Mundial (NOM) através dos BRICS.

\section{Breve Contextualização do Binômio EUA versus BRICS $^{2}$}

7 Desde a Revolução Industrial, passando pelas duas grandes guerras mundiais até a Guerra Fria (perigo vermelho), a depressão dos anos 1930 e a luta contra o terrorismo internacional e o narcotráfico, as relações internacionais baseiam-se no militarismo como trunfo para lograr fins econômicos e alianças político-militares. Ao final das duas guerras mundiais, os Estados Unidos da América (EUA) se traduziram em uma potência mundial com base no monopólio de três fatores principais, militar, político e econômico, aliados à capacidade científico-tecnológica. O mercado capitalista liderado pelos EUA aponta, especialmente a partir dos anos 1980, um saldo lastimável. Ou seja, os $50 \%$ dos mais pobres no planeta respondem por apenas $1 \%$ da riqueza global, contra os $2 \%$ mais ricos da população adulta que detêm mais de $50 \%$ dos ativos mundiais. De acordo com informações veiculadas na mídia e em debates acadêmicos recentes, $1 \%$ de cidadãos do mundo seriam proprietários de $47 \%$ da riqueza mundial.

0 interesse norte-americano pelo gás e energia da Eurásia ${ }^{3}$ fez desta região o eixo geopolítico mundial, por ser considerada, sob o ponto de vista econômico, a mais produtiva e mais avançada do mundo. Na Eurásia, "viviam $75 \%$ da população mundial e estavam depositadas $3 / 4$ das fontes de energia conhecidas em todo o mundo" (BANDEIRA, 2008, p. 11). O autor continua indicando que, com a queda da União Soviética, a partir de 1989, perdendo o domínio sobre o Leste Europeu, o Báltico e a Ásia Central, abriu-se um vácuo político que os EUA ocuparam. Uma queda celebrada por Fukuyama em um artigo de 1989 (posteriormente retomado em Fukuyama, 1992, p. 11) como "legitimidade da democracia liberal como sistema de governo, à medida que ele conquistava ideologias rivais como a monarquia hereditária, o fascismo e, mais recentemente, o comunismo". Bandeira (2008) e Wallerstein (2002) partilham a ideia de que a Grande Depressão de 1930 e o fim da Guerra Fria endossaram múltiplas vantagens para os EUA: i) possibilitaram o controle das maiores fontes de energia, gás e petróleo; ii) permitiram a ocupação, através das alianças militares, dos estados emergentes saídos dos escombros da União Soviética; iii) possibilitaram diligências para ocupar o Afeganistão e o Iraque; iv) impediram a militarização da União Européia fora da Organização do Tratado do Atlântico Norte (OTAN) ${ }^{4}$; v) impediram a remilitarização do 
Japão e da Rússia e desencorajaram qualquer desafio à sua preponderância ou tentativa de reverter a ordem econômica e política internacional por eles (EUA) estabelecida.

Assim, para Bandeira (2008), a primeira missão política e militar dos EUA após a Guerra Fria consiste em impedir o surgimento de algum poder rival a ele, seja a partir da Europa, da Ásia ou mesmo da extinta União Soviética. A estratégia geopolítica norteamericana orienta-se por três grandes imperativos que são "impedir a coalizão e preservar a dependência dos vassalos mais poderosos em questões de segurança, manter a submissão e a obediência das nações tributárias e prevenir a unificação dos bárbaros" (PANITCH e GINDIN, 2004, p. 20).

Todavia, Wallerstein (2002) não vê nenhuma vitória do capitalismo sobre o socialismo, mas sim, uma fase de transição do liberalismo para o pós-liberalismo. Deste modo, 1990 representa o fim do imperialismo norte-americano (1945-1990), uma visão que tem ganhado maior visibilidade desde 2001, quando o Grupo Econômico Goldman Sachs cunhou o acrônimo BRICs para fazer referência aos maiores mercados econômicos emergentes. Para caracterizar a era do imperialismo norte-americano, $60 \%$ das pessoas entrevistadas por Hobsbawn (1995, pp. 11-12) aplicaram uma das seguintes expressões: “[...] era o mais terrível da história; terríveis acontecimentos; massacres e guerras; século de opressão; mais violento da história; catástrofes e tragédias; [...]”. Essa experiência de terríveis acontecimentos gerou um sentimento anti-americano, sobretudo com a invasão ao Iraque em 2003, mesmo junto aos tradicionais aliados.

11 Embora a gênese dos BRICS seja essencialmente econômica, ao discutirem sua emergência, muitos autores transpõem a linha divisória entre o econômico e o político, fazendo com que os BRICS sejam vistos também como uma panacéia da política internacional. Os BRICS são, assim, tomados como os países que jogam o maior protagonismo na instauração de uma nova ordem mundial. Um dos impasses a essa ansiedade pela construção de um mundo de consensos e livre de guerras é o poder militar norte-americano. Embora as guerras no Vietnã, Afeganistão e no Iraque tenham mostrado um fracasso de tal militarismo, ele continua, como indica Cepik (2009), maior do que a soma do poder militar da China, Reino Unido, Alemanha, França, Japão, Rússia, Índia e Brasil.

O que justifica a ansiedade por uma nova ordem mundial é a ditadura político-militar norte-americana caracterizada por guerras terríveis, como, por exemplo, no Vietnam, na Coreia, Iraque, Afeganistão, Líbia, Síria e Palestina; a distribuição das dívidas públicas em quase todos os países do terceiro mundo através das instituições da Bretton Woods, gerando milhões de pessoas expostas ao pauperismo; os embargos econômicos a todos os países rebeldes; o despotismo junto aos organismos internacionais, como a Organização Mundial do Comércio e Organização das Naçães Unidas; o enfraquecimento e destruição dos regimes políticos dos Estados Nacionais não leais às ordens norte-americanas.

13 É nesse contexto - no qual um Estado nacional de excelente democracia interna, mas de autoritarismo internacional - que o mundo procura formas de nova ordem mundial. $\mathrm{Na}$ perspectiva de construção de uma NOM, Theotonio dos Santos (2012) coloca uma pergunta fundamental: What Kind of Basic Changes do We Need in the New World System? Para encontrar os elementos da nova ordem e tipos de mudanças, como indaga Theotônio, é importante analisar o antagonismo EUA e BRICS.

14 Se, por um lado, os EUA e seus aliados da Europa Ocidental e o Japão se encontram mergulhados numa crise financeira aguda, por outro lado, o Brasil, a Rússia, a Índia, a 
China e a África do Sul (BRICS) ${ }^{5}$ observam uma prosperidade econômica jamais vista na história econômica mundial. A dicotomia reside no fato de a prosperidade econômica desses países apenas suplantar os EUA em termos econômicos e não em termos militares. Como se sabe, e de acordo com Nogueira e Messari (2005), em política, o choque de interesses envolve, por natureza, a possibilidade do uso da violência. Este paradoxo (militarismo americano e emergência econômica dos BRICS) constitui, desde 2007, o centro de análise de muitos estudiosos curiosos, cujas reflexões teóricas indagam sobre até que ponto os BRICS podem realmente estabelecer uma nova ordem econômica mundial.

Durante a Guerra Fria, por exemplo, os fatores de legibilidade e reconhecimento do estatuto de país hegemônico estavam associados à:

posse de armas nucleares [...], mas, após fim do socialismo, a aquisição de capacidade nuclear com fins bélicos se tornou um comportamento inaceitável, vulnerabilizando o detentor dessa capacidade, atualmente, o poder e a importância geopolítica, peso econômico e grau de integração à economia global, trajetórias culturais e históricas distintas e sistema político doméstico, constituem alguns dos requisitos fundamentais de legibilidade a um grande potência internacional (HURRELL, 2009, p. 15).

Chellaney (2014) suaviza o debate das questões militares ao considerar que, mesmo se o poder militar norte-americano permanecer intacto, a natureza atual de tal poder está mudando no contexto do processo evolucionista e não revolucionário como no passado histórico. Para este autor, o Ocidente só tem $12 \%$ da população mundial, a ordem transatlântica deve dar lugar a uma nova ordem internacional. Para Chellaney, trata-se de uma ordem de consumo, de interdependência entre os países no comércio internacional, cujos resultados mostram uma passagem de 1.4 para 2.4 trilhões de dólares de 2000 a 2010, respectivamente. Para este autor, as teorias tradicionais de emergência de países com poder militar já foram substituídas por paradigmas de emergência de países interdependentes no e para o desenvolvido econômico.

O ponto central defendido por Chellaney é de que as atuais relações guiadas pela globalização no contexto do comércio internacional ultrapassam em larga medida as questões militares e diferenças culturais.

Não obstante este posicionamento, o imperialismo norte-americano de "economia global onde todos somos 'interdependentes' continua oprimindo povos e nações, e semeando por onde passa dor, destruição e morte" (BORON, 2002, p. 12). Para conseguir este intento, o imperialismo recorre, sempre que necessário, aos quatro indicadores de poder apresentados por Trein (2011), nomeadamente, militar, econômico, político e capacidade científico-tecnológica. Estes três poderes e a capacidade científicotecnológica conferem aos EUA uma posição de supremacia nas relações internacionais. Os efeitos dessa supremacia são lastimáveis, desde distribuição de guerras gratuitas, genocídio financeiro ao terceiro mundo através das instituições da Bretton Woods, até as cruéis práticas descritas por Hardt e Negri (apud BORON, 2002, p. 30) no seu conceito de modernidade. Trata-se de "..."guerras fratricidas", de "desenvolvimento" arrastador, "civilização" cruel e violência nunca antes imaginada, [...] campos de concentração, armas nucleares, guerras genocidas, escravidão e apartheid." Cabe reiterar, aqui, que esses genocídios são praticados por um Estado considerado de excelência em termos de democracia nacional, mas de postura incisivamente ditatorial em termos de suas relações internacionais em todos os campos. É esse Estado nacional que dita as políticas de guerra em busca da democracia, liberdade e justiça dos povos. 
Após a promoção das guerras civis, os mesmos EUA ditam, através das suas instituições financeiras, as regras de reconstrução nacional, as normas de investimentos para o crescimento econômico e depois para o desenvolvimento, cujo resultado é miséria e pobreza absoluta. Desde a fundação, em 1944, do Fundo Monetário Internacional (FMI), o mundo parece não conhecer nenhum país fora do Ocidente que tenha se desenvolvido graças a esta instituição. Prevalecendo apenas o comando, como mostra Atilio Boron, do duplo padrão com o qual os EUA julgam os governos e suas ações:

Um padrão é utilizado para avaliar a soberania dos amigos e aliados dos Estados Unidos; outro bem diferente é o que se usa para julgar a dos neutros ou dos inimigos. A soberania nacional dos primeiros deve ser preservada e fortalecida, a dos segundos deve ser enfraquecida e violada sem qualquer tipo de escrúpulos ou falsos problemas de consciência (BORON, 2002, p. 90).

19 Para perceber melhor as metamorfoses da ditadura internacional norte-americana, dos padrões de enfraquecimento ou violação dos Estados nacionais, é importante apresentar o pensamento do historiador hondurenho Ramón Oquelí, citado por Boron, ao afirmar que:
A importância das eleições presidenciais com ou sem fraude, é relativa. As decisões que afetam Honduras são tomadas primeiro em Washington, a seguir, no comando militar norte-americano no Panamá (o Southern Command), depois, no comando da base norte-americana em Palmerola, aqui em Honduras; em seguida, a embaixada norte-americana em Tegucigalpa; em quinto lugar, vem o chefe das forças armadas hundurenhas, e, apenas em sexto lugar, aparece o Presidente da República. Votamos pois em um funcionário de sexta categoria, quanto ao poder de decisão. As funções do presidente se limitam à administração da miséria e à obtenção de empréstimos norte-americanos (OQELÍ apud BORON, 2002, p. 98).

Esta situação infelizmente não acontece apenas em Honduras, mas também em qualquer outro país da América Latina, como mostra Ramón Oquelí, como em todos os países do terceiro mundo. Aliás, esses países são assim considerados porque seguem rigorosamente as terapias do Consenso de Washington impostas pelos EUA. Qualquer desobediência resulta em ao menos um dos elementos da seguinte trilogia: guerra civil, golpe de Estado e sanções e/ou embargo econômico. Os países vítimas desta trilogia são a maioria, em nível mundial, quase todos os países da África, da América Latina e Central e do Caribe, da Europa do Leste e Asiáticos.

21 Perante esse cenário caótico, a questão fundamental no contexto das ações de instauração de uma NOM deve ser, também, aquela que busca garantias à humanidade sobre o comportamento que os BRICS irão tomar para evitar cair no mesmo cenário ou, na linguagem de Albert Hirschman, "substituir um desastre por outro".

Aliás, esta é a profecia de Wallerstein (2002), que prevê um futuro cheio de incertezas, chegando a apelidar de purgatório, embora as perspectivas de maior crescimento econômico do Norte apontadas por este autor tenham sido desautorizadas com a atual crise, na qual, contrariamente à previsão dele, o Sul registra ascensão.

Fukuyama (1992, p. 21), socorrendo-se do conceito do desejo de reconhecimento, deduz que a "revolução liberal que elimina a relação senhor-escravo, transformando os escravos em seus próprios senhores teria efeito similar na relação entre os Estados". 0 autor continua apontando que a "democracia liberal substitui o desejo irracional de ser reconhecido como maior do que os outros pelo desejo racional de ser reconhecido como igual". Estas duas premissas permitiram ao autor chegar à conclusão de que a democracia liberal teria menores incentivos para a guerra, dado o reconhecimento 
recíproco da legitimidade entre todas as nações. Ele está muito certo ao aplicar a expressão "menores incentivos para a guerra", todavia, as motivações para a guerra não estão associadas apenas ao regime político, mas, sobretudo, aos fatores econômicos. Os EUA, por exemplo, são os que mais guerras e golpes de Estado fomentaram nos últimos 50 anos em nome de controle do petróleo. Este Estado nacional não se considera igual a outros Estados, existe nele uma sensação de alto sentido de superioridade. Fukuyama parece não querer reconhecer que o que mudou não é necessariamente relativo às mortes de pessoas, mas às formas como essas pessoas morrem.

Se no passado a guilhotina, a escravidão, as terríveis e tremendas guerras eram os fatores das mortes, hoje em dia, as destruições e ataques perpetrados por um dos Estados com a melhor democracia liberal, a pobreza extrema conseqüente dos endividamentos dos Estados, via instituições da Bretton Woods, a falta de medicamentos nos hospitais, a criminalização da pobreza, a luta pelo terrorismo e narcotráfico, entre outros fatores que evidenciam egoísmo exacerbado, continuam a matar milhões de pessoas em todo o mundo. Sob o guarda-chuva de liberdade e justiça, foi adiado o futuro do Iraque, da Líbia, da Palestina e atualmente da Síria, da Ucrânia, da Tchetchênia, entre outros Estados. Nesse contexto, cabe perguntar: até quando as pessoas poderão gozar o direito à vida e à morte natural? Até quando a humanidade poderá pensar em ter zero morte por guerra, fome, crime entre outros fatores humanos? Que civilização, modernidade, industrialização, desenvolvimento, liberalismo, democracia, entre outros conceitos nobres, são esses que colocam mais da metade da população mundial à beira da morte?

Não se pretende defender que estes conceitos nobres não sejam desejáveis, mas se a sua implementação significar morte de pessoas, então eles são vazios de conteúdo de humanismo. Os promotores das guerras não imaginam o quanto a humanidade sairia a ganhar se pudesse existir pelo menos um dia em que nenhuma bala fosse disparada.

Outra profecia que é assumida por este artigo é dada por Dos Santos (1993) ao desenhar um futuro sereno no qual a liderança da hegemonia mundial é partilhada, conduzindo a uma civilização planetária que seja a síntese de várias civilizações, um caminho de entendimento, de paz, de correção das desigualdades mundiais, de concentração de metas e políticas globais. Para sustentar este argumento, o autor recorre ao fim da guerra fria como motivo pelo qual já não se justifica mais o militarismo agressivo. A influência das potências médias em emergência, como a China, Índia, Brasil, Turquia, México, Coréia do Sul, Taiwan, Singapura, Hong Kong, é apontada por Theotonio dos Santos como fator decisivo para a construção da nova ordem mundial. Esta é a visão real da civilização inclusiva, de consenso e de correção das desigualdades mundiais.

De fato, são os fatores econômicos que guiam o atual processo de mudanças estruturais. Todavia, é de esperar que os investimentos na área militar continuem a registrar crescimento ainda que isso não signifique necessariamente guerras. Dois argumentos fundamentais: o dilema da segurança e experiências do passado que levam cada país proteger o seu território, a sua população e o patrimônio gerado pelo desenvolvimento econômico. A posição de que os investimentos militares irão continuar está ancorada nos dois fatores apontados, mas também na necessidade de estabelecer o equilíbrio do resto dos países em associação, em particular os do sul, com o monstro militar norteamericano. Porém, isso não significa aceitar um futuro de guerras, mas mostrar que a base da economia norte-americana é militar. Como esse Estado nacional vai levar muito 
tempo para se conformar com sua queda, as probabilidades de guerras por ele provocadas não são nulas.

Este pensamento parece se opor à lógica de Maquiavel (2014, p. 15) ao afirmar que "se o príncipe engana, não pode pretender que os outros não façam o mesmo”. A dedução lógica a este princípio de Maquiavel aponta que, da mesma maneira que os EUA se comportaram militar, política e economicamente, os BRICS têm maior probabilidade de se comportar à semelhança do Príncipe.

Esta dedução não é tão linear, dado que o futuro depende, sobretudo, da participação dos países na instauração de uma NOM. O contexto de mercados econômicos emergentes que deu origem aos BRICS, de acordo com o Grupo Econômico Goldman Sachs, distribuiu o poder por todos os continentes, prevendo-se a entrada da Nigéria - o que irá reforçar o poder sul-africano - para influenciar mais países desse continente.

$31 \mathrm{Na}$ Cúpula dos BRICS ocorrida em Fortaleza, por exemplo, houve encontro com 33 países da Comunidade de Estados Latino-americanos e Caribenhos (CELAC). A participação dos países na definição do futuro não só econômico como também político-militar poderá reduzir a ditadura militar nos assuntos da economia política internacional.

O princípio teórico do mercantilismo vê a economia a serviço da política. Isto levaria à ideia de que o desenvolvimento econômico dos BRICS é um instrumento para lograr fins políticos de nova hegemonia política mundial. Jackson e Sorensen (2007, p. 245) apontam que "a economia internacional é uma arena de conflitos entre interesses nacionais opostos ao invés de uma arena de cooperação e ganho mútuo". Se a análise basear-se na Rússia como um país, no seio dos BRICS, com maior freqüência de envolvimento em guerras regionais e internacionais, por exemplo, na Geórgia, na Tchetchênia, na Ucrânia, entre outras, pode se deduzir um futuro de guerras. Mas se o mesmo exame for feito a partir da China, o maior gigante econômico da união e com o maior exército em termos numéricos e de investimentos militares do mundo, a indução seria de paz. Por exemplo, a China é regionalmente uma potência militar e com relações de eminência de guerra a qualquer momento com os seus aproximadamente 24 países vizinhos. Tal fato de guerra vem reduzindo desde o governo de Deng Xiaoping e os problemas políticos estão sendo "ultrapassados" a favor de relações econômicas. $O$ poder econômico expressivo da China na união ao lado do governo do ANC, que desde que alcançou o poder em 1994 tem tido relações de paz na região da África Austral, faz esperar um futuro cada vez melhor. Este posicionamento não significa o fim da pobreza, porque isso depende da participação de cada país, mas, sim, aponta para boas relações tanto em nível político quanto econômico.

\section{Breve Análise da Dualidade de Crises Norte- americanas}

33 A profecia de Marx e dos marxistas sobre a estagnação do capitalismo como conseqüência da sua expansão e suas próprias contradições tem sido objeto de estudo dentre os marxistas desde o século XIX. Isto mostra que as crises do capitalismo como sistema econômico são parte indissociável do próprio sistema, numa alternância das fases de Kondratieff A e B, como descrevem Wallerstein (2002) e Dos Santos (2004) e (1993). Theotônio dos Santos destaca o estudo do economista russo Kondratiev, que 
constatou a existência de três ciclos econômicos de 50 a 60 anos entre 1780 e 1920 . Avança ainda trabalhos posteriores de Tugan-Baranovisky, Lenine e Parvus, que também contribuíram na visualização das ondas longas desde 1905, mostrando que, mesmo desde o século XVIII para cá, o capital regenera-se através de crises cíclicas. As ilustrações de Dos Santos (2004, p. 149) apresentam ciclos longos de crise e recuperação do capital, ou seja, entre 1790 até 1810-17, ascensão e declínio, que durou de 1810-17 até 1844-51, seguido de recuperação, que se deu de 1844-51 até 1870-75, e do decrescimento, que ocorre de 1870-75 até 1890-96, etc. Em o "Enigma do Capital”, David Harvey mostrou que é possível, por exemplo, identificar em apenas um curto período, de 1973 a 2009, 13 principais crises nas várias regiões do mundo, destacando-se que a duração das duas mais longas foi de 8 anos.

Estes dados apenas têm a finalidade de demonstrar que o capitalismo se regenera por meio de crises. Aceitando-se esta realidade, o que faz da atual crise dos EUA uma crise transição, ou seja, crise de sucessão? Aliás, esta é uma das questões centrais deste artigo, cuja busca de resposta percorre todo o texto. Todavia, em Dos Santos (1993) é possível perceber que a atual crise norte-americana não é o único fator decisivo para a transição hegemônica. A emergência de novos mercados econômicos em todos os continentes reduz a supremacia do monstro econômico e político norte-americano. A crise junto aos aliados e as manifestações populares que demonstram uma atitude antiamericana em todo o mundo constituem outro fator de destaque para aceitar que esta é a era de crise transição.

As explicações teóricas existentes sobre a crise norte-americana são contraditórias, umas apresentam uma crise de caos nos EUA e outras são minimalistas. Kregel (2009), por exemplo, aplica a expressão "relativas dificuldades no mercado hipotecário" do subprime dos Estados Unidos, que se espalhou por todo o seu sistema financeiro e depois pela Europa, para descrever a crise. A partir de duas premissas, o autor faz uma dedução lógica, ou seja, se a crise é de liquidez, então a solução é resolver esse problema de liquidez para que os preços se estabilizem e os bancos possam prover empréstimos. Em Harvey (2011, p. 12) é possível perceber que o governo de Bush foi injetando dinheiro "sem qualquer controle, para todas as instituições financeiras consideradas grandes demais para falir". Todavia, o mercado de crédito permaneceu congelado e a crise continua.

Em "O Enigma do Capital" David Harvey apresenta uma situação não apenas contrária à descrita por Kregrel, mas profundamente lastimável sobre a crise norte-americana. Para este autor a crise norte-americana iniciou em 2006, mas como afetava pessoas de baixa renda, os políticos e a mídia não deram nenhuma atenção. Quando em 2007 ondas de despejos de famílias alcançaram a classe média branca as autoridades começaram a se pronunciar. Nessa altura, que se pode considerar tardia, a onda de despejos já estava na ordem de 2 milhões de pessoas e outras 4 milhões em eminência. Para além da dramática situação de despejos de pessoas por falta de pagamento de aluguéis, deixando casas vazias e pessoas nas ruas, o sistema financeiro foi demasiadamente afetado. Tal é o caso do desabamento do banco de investimento Lehman Brothers no dia 15 de setembro de 2008 e, como consequência, "os mercados globais de créditos congelaram, assim como a maioria dos empréstimos do mundo" (HARVEY, 2011, p. 10). O autor cita o Fundo Monetário Internacional (FMI) que estimou perdas no mercado imobiliário de 93 bilhões de dólares e uma destruição de 50 trilhões de dólares, 
equivalente à produção total de bens e serviços mundiais de 1 ano. As exportações da China, Japão, Coréia do Sul e Taiwan caíram 20\% em apenas 2 meses.

O Relatório Econômico Anual do Presidente dos EUA apresentado ao Congresso em março de 2014 mostra uma situação de relativa calma e alavancamento da economia norte-americana. $O$ relatório aponta que, após 5 anos de persistência e determinação, os EUA podem melhor se posicionar no século XXI. As principais evidências para sustentar esse melhor posicionamento são: i) crescimento econômico com 8.5 milhões de novos empregos criados no sector privado até 2013, o que faz com que o índice do desemprego dos EUA fosse o mais baixo nos últimos 5 anos; ii) pela primeira vez, nos últimos 20 anos, os EUA produzem mais petróleo e gás em casa, posicionando-se, em 2013, ao lado da Rússia e da Arábia Saudita, e exportam mais produtos manufaturados; iii) o investimento em habitação alcançou cerca de $6 \%$ e em automóveis $9 \%$ na quarta metade de 2013; iv) 5.3 milhões de americanos foram salvos da pobreza através de programas como: segurança social, taxas de créditos, assistência nutricional e extensão da assistência aos desempregados; v) expansão da inovação das tecnologias de comunicação, especialmente na rede de wireless de banda larga, cujo investimento cresceu de 2009 a 2012 em mais que $40 \%$, ou seja, de $\$ 21$ bilhões para $\$ 30$ bilhões, e atualmente os EUA lideram, em nível mundial, os mais avançados serviços de $4 \mathrm{G}$ wireless de banda larga.

Apesar destas melhorias, a crise norte-americana e da zona Euro é descrita por Harvey (2011) como a pior desde os anos 70. O mesmo relatório ora citado reconhece, por exemplo, que a recessão criou uma estagnação de 8.8 milhões de trabalhos no setor privado jamais vivida após a Segunda Guerra Mundial. Aponta ainda que a economia dos EUA ainda não está restaurada ao seu máximo potencial. Para melhorar esta situação, o relatório aponta três imperativos: o primeiro e imediato consiste em continuar a restaurar a economia para o seu máximo potencial; o segundo, expandir o potencial econômico, e; o terceiro é assegurar que a economia providencie a todos os norte-americanos grandes oportunidades para realizarem as suas potencialidades individuais e experimentar prosperidades.

Intervindo no debate sobre a crise norte-americana e progressiva substituição do dólar americano como moeda internacional ${ }^{6}$, Medeiros e Serrano $(2008$, p. 83) apresentam um quadro lastimável, que este artigo descreve como crise transição. Para estes autores, "na segunda metade dos anos 1980, os EUA se tornaram devedores externos líquidos e atualmente são os maiores devedores externos líquidos do mundo em termos absolutos [...]." Assistem, desde 2007, a desvalorização do dólar em relação ao Euro e outras moedas internacionais, a explosão do preço do petróleo e sua suposta crescente escassez que é atribuída, em parte, à derrota dos EUA no Iraque.

Forte recessão e aceleração da inflação nos EUA e não só, mas também, gastos das famílias americanas. Luft (2009), no seu artigo intitulado "Crise - a dimensão humana", aponta algumas contradições do discurso político que aconselha as famílias a gastar com tranquilidade: "comprem, [...] os governos estão aumentando gastos públicos". Tal como Kregel (2009), que classificou a crise norte-americana em "relativas dificuldades" no mercado hipotecário subprime, Medeiros e Serrano (2008) não julgam haver condições de um total colapso do imperialismo americano.

41 Tal confiança na estabilidade norte-americana foi comentada pelo Prof. Elmar Altvater na sua nona aula na Universidade do Estado de Rio de Janeiro (UERJ), em 2012, sobre a "guerra das moedas", ao defender a segurança e disponibilidade do dólar em nível 
internacional. Medeiros e Serrano (2008, p. 85) se apóiam em dois argumentos para negar a crise transição. $O$ primeiro indica que os muitos autores que acreditam no colapso norte-americano não "levam devidamente em conta o fato de que praticamente a totalidade dos passivos externos americanos é denominada e praticamente toda a exportação de bens e serviços dos EUA são pagas exclusivamente em dólar". 0 segundo argumento aponta que "as evidências recentes revelam que o crescimento da economia norte-americana tem sido limitado pela demanda agregada e não pela oferta”. David Harvey, ao estudar as dezessete contradições do capitalismo, retoma a crise de subconsumo defendida por Rosa Luxemburgo. Ou melhor, grandes volumes de mercadorias produzidas sem consumidores geram uma série de barreiras na infinita realização do capital, descrita do Marx. Deste modo, o argumento baseado na oferta dado por Medeiros e Serrano parece ignorar que a realização do capital depende tanto da oferta quanto da demanda.

Outros contra-argumentos apontam uma forte desaceleração e baixa taxa de crescimento da economia norte-americana. O crescimento médio entre 2001 e 2007 foi de $2,4 \%$ ao ano. Esta taxa de crescimento não se manteve como crê a profecia de Medeiros e Serrano, como também baixou o que constitui a taxa de crescimento de todo o período pós-guerra. Os tradicionais aliados econômicos americanos, a Europa e em particular a zona Euro e o Japão, apresentam, de acordo com o Relatório dos EUA de 2014, uma taxa de desemprego recorde de $12.1 \%$ entre abril e setembro de 2013 . A inflação declinou para 0.8\% em 2013, embora o Banco Central Europeu tenha registrado uma estabilidade de preços perto de $2 \%$. O Produto Interno Bruto (PIB) real do Japão cresceu 2.7\% em 2013, contra o acentuado declínio de $0.4 \%$ em 2012. O Índice do Preço de Consumo (CIP) (que inclui comida e energia) registrou uma positividade de $0.7 \% \mathrm{em}$ 2013, contra $0.6 \%$ de 2012 .

Se, por um lado, o relatório americano aponta melhorias de relações interbancárias e de liquidez no Banco Popular Chinês e a paz do PIB real nas economias emergentes, como Indonésia, México, África do Sul, Malásia e Tailândia, o crescimento só se fez sentir em países como Brasil, Índia e Turquia. Por outro lado, o relatório do Programa das Nações Unidas para o Desenvolvimento (PNUD) de 2013 ressalta a ascensão do sul e indica que:

Pela primeira vez em 150 anos, o produto combinado das três principais economias em desenvolvimento - o Brasil, a China e a Índia - é aproximadamente igual aos produtos internos brutos (PIB) combinados das antigas potências industriais do Norte: Canadá, França, Alemanha, Itália, Reino Unido e Estados Unidos (PNUD, 2013, p. 1-2).

O relatório continua mostrando que os avanços econômicos foram registrados quase por todos os países do sul, mas, sobretudo, por países como África do Sul, México, Indonésia e Turquia. Juntam-se nessa lista países de economias pequenas, como Bangladesh, Chile, Gana, Maurícias, Ruanda e Tunísia. Se em 1950 as tradicionais economias mundiais respondiam por mais de metade do percentual da economia mundial e China, Índia e Brasil por apenas 10\%, até 2050, estima-se que estes três países venham representar $40 \%$ da economia mundial. De 1980 a 2010 a participação do sul no comércio mundial de mercadorias passou de $25 \%$ a $47 \%$ e no produto mundial passou de $33 \%$ a $45 \%$ e o comércio Sul-Sul aumentou de $8,1 \%$ a $26,7 \%$. Em termos do Índice de Desenvolvimento Humano (IDH), o relatório aponta que de 1990 a 2012 mais de 40 países registraram ganhos mais significativos do que o previsto. Maiores progressos foram assinalados nos países do sul. De acordo com Scerri (2014), o IDH não é só um indicador da qualidade de vida das pessoas, também ajuda a medir a capacidade do 
potencial humano. A melhoria da qualidade de vida e da capacidade humana é um bom indicador para perspectivas de desenvolvimento.

Outros dados apresentados nos relatórios estatísticos dos BRICS entre 2010 a 2014 apontam que os $\mathrm{R}^{7}$ apresentam, atualmente, o maior mercado econômico, com $40 \%$ da população mundial contra $12 \%$ da população das tradicionais economias do norte, sendo que os restantes $48 \%$ estão nos países subdesenvolvidos. Dois países dos BRICS apresentam indicadores de pleno emprego, a Índia e a China, portanto, com índice de desemprego de $2.2 \%$, contra $5.5 \%, 6.1 \%$ e $25.1 \%$ da Rússia, Brasil e África do Sul respectivamente. A esperança de vida é maior no Brasil e China, com 74.8, seguida da Rússia e Índia com 70.7 e 66.1, na mesma ordem e, por fim, a África do Sul, com 58.1 anos. Em termos de percentagem de PIB gasta em educação, em 2010 a África do Sul gastou $10.1 \%$, contra $5.1 \%$ do Brasil e $4.1 \%, 3.7 \%$ e $3.1 \%$ da Rússia, China e Índia, respectivamente. Estes dados conjugados com as iniciativas que os BRICS têm colocado em prática, como a criação do Banco dos BRICS e os apelos políticos para um mundo mais justo e consensual, asseguram que estes países vão desempenhar com zelo o papel de instauração da NOM. O Grupo Econômico Goldman Sachs afirma que os BRICS jogam atualmente um maior protagonismo em vários organismos internacional como, por exemplo, Organização Mundial de Comércio (OMC), ONU, G20 e na Convenção das Nações Unidas para mudanças climáticas.

Para além da crise econômica, os EUA experimentam desde 2003 uma crise de autoridade nos assuntos internacionais. Quando dos preparativos para a invasão do Iraque, como mostra Chomsky (2004), os EUA se depararam com um fracasso dos assim chamados "esforços diplomáticos". Tal fracasso, da adesão dos tradicionais aliados norte-americanos, é apontado não apenas como produto da consciência dos governos aliados sobre a brutalidade e injustiça que ia ser impressa sobre o Iraque, mas, sobretudo, pelas manifestações populares contra tal aliança em todo o mundo. A "melhor aluna", por exemplo, a Turquia, que cansada dos castigos norte-americanos "aprendeu a lição", "não conseguiu fazer com que o parlamento respaldasse o papel que os EUA haviam reservado ao país, descartado por 95\% da população" (CHOMSKY, 2004, 165).

O mesmo cenário, de delegar o poder decisório para a participação na guerra, foi adotado pela França e Alemanha, entristecendo bastante o governo de Bush. Esta estratégia não foi adotada pelos tímidos governos da Itália, Espanha e obviamente do Reino Unido, apesar de as suas populações terem se manifestado em oposição à invasão. $\mathrm{Na}$ Cúpula de Açores, o Conselho de Segurança das Nações Unidas tentou sem sucesso travar tal invasão, quando Bush declarou "façam o que dizemos ou tornam-se irrelevantes" (Ibidem). De acordo com Chomsky, após a derrubada de Saddam Hussein, vários estudos foram realizados em alguns países da Europa e os resultados apontam para a total indignação das pessoas pela invasão, gerando inclusive atitudes antiamericanas. Essa situação foi vivida em todos os cantos do planeta, ou seja, manifestações populares contra a invasão, sobretudo nas grandes cidades. Para este artigo, a aliança da Itália, Espanha e Reino Unido à invasão ao Iraque e o apoio dado pela África do Sul ${ }^{8}$ significam uma aderência de sobrevivência contra a superpotência e não necessariamente de reafirmação de boas relações de amizade.

Bond (2005), ao confrontar os discursos de anti-guerra ao Iraque de Nelson Mandela e Thabo Mbeki com a prática chega à conclusão de que “[...] tem-se a lógica impressão de que o movimento antiimperialista tem como aliado um importante Estado da África, [...] 
infelizmente esta postura pode ser entendida como falar pela esquerda e andar pela direita [...]" (Bond, 2005, p. 240). A partir dos problemas internos da África do Sul, como as subjacentes dinâmicas de acumulação e luta de classes geopolíticas, o autor deduz, à semelhança de Boris Kagarlitsky para o caso russo, que a liderança sul-africana está a serviço da superpotência global. Ma o mesmo autor apresenta uma citação importante para a análise do comportamento dos líderes sul-africanos na sua relação com EUA, ao afirmar que, para Mandela, não se pode permanecer em tensão com uma grande potência. $\mathrm{O}$ autor cita ainda que, durante uma manifestação de 4 mil pessoas diante da embaixada norte-americana na Pretória, o secretário-geral do Congresso Nacional Africano (ANC), Kgalema Motlanthe, disse: posto que estamos dotados de muitos minerais ricos, se não determos hoje esta ação unilateral contra o Iraque, amanhã virão por nós (Bond, 2005, p.239). Nota-se que, no segundo caso, existe uma atitude de relutância quando à invasão e, no primeiro caso, e acreditando-se que Bush insistiu no pedido de apoio, os líderes sul-africanos se aperceberam da possível tensão futura a que Mandela faz alusão e como estratégia de sobrevivência apoiaram.

49 A estratégia de sobrevivência parece conforme o adágio popular "o pobre não se zanga", porque não foi possível expressar com eficácia a zanga, frente à tremenda fragilidade, vulnerabilidade, impotência militar, política, econômica e tecnológica contra um Estado nacional que funciona com a lógica daquilo que Perry Anderson designou de "humanismo militar". Mas mesmo com esta cedência da liderança sulafricana, a fúria da esquerda junto a 300 organizações manteve as manifestações contra a guerra no Iraque. Numa demonstração de poder e agradecimento pelo apoio dado, Bush visitou a África do Sul em julho de 2003.

Para melhor perceber a estratégia de sobrevivência dos países, quando analisados isoladamente, examina-se o caso da única potência política, militar e diplomática que foi historicamente obstáculo para os EUA, a Rússia. O estudo de Kagarlitsky (2005) sobre "O Estado Russo na Era do Império Norte-Americano" chegou a conclusões semelhantes às de Bond para o caso sul-africano. Boris Kagarlitsky aponta duas correntes antagônicas sobre o Governo de Vladimir Putin e sua relação com o império: a primeira que considera o governo de Putin patriota e anti-americano, entendendo que este defende o país das ambições imperialistas, e; a segunda que vê Putin como um mero títere norte-americano. Kagarlitsky afirma que "o patriotismo de Putin não é mais (nem menos) honesto que seu desejo proclamado de manter a democracia na Rússia" (p. 303). $\mathrm{O}$ autor usa como evidências as inúmeras concessões aos líderes americanos, tal é o caso do: i) fechamento das bases russas no Vietnã e em Cuba; ii) estabelecimento anuído pela Rússia das bases estadunidenses na Ásia Central, e; iii) colaboração econômica entre os dois governos.

51 O texto de Kagarlitsky é contraditório, porque ao mesmo tempo em que não crê que o governo de Putin possa ser qualificado como um mero títere norte-americano, afirma também que "as declarações de Putin contra a invasão ao Iraque [...] não tiveram nenhum impacto em Washington e nem sequer se refletiram nas relações entre os EUA e a Rússia" (p. 304). o que aconteceu na verdade, continua o autor, foi a compreensão por parte do governo de Bush da debilidade russa e da sua dependência aos EUA. Reconhecendo as contradições do governo de Putin, que pode ser qualificado às vezes como "nacionalista" e outras vezes como intermediário norte-americano, o autor indica que tal fato reflete as contradições da economia política russa e total falta de coerência da política externa. 
52 Seja como for, para este artigo, as fragilidades de cada um dos países dos BRICS devem ser vistas considerando-se o poderio norte-americano. Nenhum país sozinho pode fazer face à tamanha ditadura deste Estado nacional norte-americano, mas todos unidos, econômica, militar e politicamente, tornam possível tal oposição. A experiência russa no enfraquecimento da hegemonia americana e em relação ao poder militar, aliado atualmente à prosperidade econômica, pode, junto aos outros membros dos BRICS, contrabalançar o poder norte-americano. Aliás, a condução do processo transitório não é responsabilidade exclusiva dos BRICS, é de todos os países do mundo. Dos Santos (1993, p. 14-15) já demonstrou, muito antes da cunhagem do termo BRICS e afirmação de acordos por estes países, que "a articulação inevitável da antiga URSS na economia mundial e seu papel mediador entre Europa e Ásia, a emergência da China, da Coréia do Norte [...] a rearticulação do Norte de África e do Oriente Médio [...], as integrações regionais [...]" são fatores importantes para a construção de um novo mundo. 0 relatório do sexto fórum dos BRICS, de 2014, aponta que o comércio deve ser visto como um caminho para o desenvolvimento socioeconômico e não o fim em si mesmo e saúda o surgimento de mega-acordos transcontinentais que, embora desafiem os acordos de livre comércio, são uma oportunidade para as relações econômicas inclusivas, capazes de mitigar a pobreza, o desemprego e as desigualdades. Assim, os BRICS aparecem como os maiores protagonistas do processo e não os únicos atores exclusivos.

Como demonstraram Nogueira e Messari (2005), os Estados têm duas possibilidades para a sua sobrevivência nacional e internacional: juntar-se a uma grande potência para ver os seus interesses nacionais e internacionais melhor servidos ou juntar-se com outros Estados menos poderosos ou com o principal Estado que compete com a grande potência para tentar equilibrar o poder daquela potência. As duas situações são atualmente manifestadas pelos Estados ${ }^{9}$ e em particular pelos BRICS. Os debates acadêmicos não são alimentados pela primeira situação, mas, sobretudo, pela segunda, ou seja, até que ponto os países emergentes podem se alinhar ao tradicional rival dos EUA, a Rússia, portanto, e constituir um bloco capaz de instaurar uma nova ordem econômica mundial?

54 A par desta pergunta, Andrew Hurrell aprecia positivamente os altos índices de crescimento econômico da China e da Índia e assevera que tem atraído atenção, motivando projeções sobre as implicações econômicas e geopolíticas globais. $O$ autor assinala que, desde os anos 90, países como a China, Índia e Brasil figuravam na lista dos 10 mercados econômicos emergentes ${ }^{10}$ e sempre foram vistos com potencial para alterar a realidade política e econômica global. De acordo com Nogueira e Messari (2005, p. 26), reiterando ideia presente em Jackson e Sorensen (2003, p. 245) a sobrevivência é tomada como único objetivo possível, "ou no mínimo, como objetivo que define todos os demais e a segurança como um bem de soma zero, isto é, a segurança de um só pode ser atingida em detrimento da falta de segurança dos outros e vice-versa". Assim, o passado histórico das relações internacionais, embora abra espaços para a cooperação, indica que o dilema da segurança projetado em 1978, de acordo com Robert Jervis, citado por Nogueira e Messari, já começou a orientar os Estados emergentes a uma real pretensão de dirigir os destinos econômicos e políticos do mundo. A partir da breve análise da dualidade de crises norte-americanas é possível acreditar numa crise transição, ou seja, passagem de um poder mundial unipolarizado para um poder polarizado, cujo papel dos BRICS será tanto quanto mais expressivo. 


\section{Oportunidades e Possibilidades para uma Nova Ordem Mundial: o papel dos BRICS}

(NOM) foram e estão sendo geradas por dois fatores: a reco política mundial após a queda da URSS e a atual crise econômica dos EUA. O que resta nesta sessão é discutir o papel específico dos BRICS no contexto da instauração de uma NOM. Os dados sobre a relevância econômica dos BRICS são sobejamente conhecidos e uma breve apresentação foi feita na segunda sessão. A finalidade desta sessão é, assim, analisar as possibilidades e o papel dos BRICS na instauração de uma NOM, considerando as duas abordagens literárias antagônicas (os pró e os contra a possibilidade de uma NOM através da liderança dos BRICS) e os avanços oficiais até aqui realizadas entre os governos dos BRICS. defendidos pelos acadêmicos chineses sobre a possibilidade de uma nova ordem econômica mundial. Os cépticos defendem a ineficiência dos BRICS para instaurar uma nova ordem econômica mundial dada à instabilidade interna dos países que integram o grupo. Na mesma linha, Brahma Chellaney, embora não seja céptico, afirma que o grande desafio dos R5 é institucionalizar as relações de cooperação. Sem clara definição dos objetivos e acordos de plano de ação, os BRICS não poderão instaurar uma nova ordem econômica mundial dentro das contradições e variações de sistemas políticos, econômicos e ambições nacionais. Os otimistas argumentam que não há dúvidas sobre o principal papel dos BRICS para estabelecer uma nova ordem econômica mundial e fornecem novas fórmulas para após o colapso do neoliberalismo. Outra corrente de pensamento é dos neutralistas, portanto, que defendem o "wait-and-see position", ou seja, preferindo delegar tudo ao processo histórico e entendendo que o papel dos homens seria esperar para ver o que vai acontecer. Seu argumento baseia-se na ideia de que é bastante cedo para avaliar o papel dos BRICS.

defender que "todos os países compartilham uma crença em seu direito a um pape mais influente em assuntos mundiais." Realmente, não é só pela crise ocidental que estes países ganharam um estatuto internacional de grande influência, mas sobretudo a sua organização econômica e política lhes conferiu uma expressão de hierarquia "suficiente para demarcar a revisão da ordem estabelecida e de suas normas dominantes de maneira a refletir seus próprios interesses, preocupações e valores" (Ibidem). Destaca, assim, a necessidade de uma nova ordem mundial, não como produto da crise norte-americana, mas sim, do comportamento ferino deste Estado nacional, em decorrência da insegurança gerada pelo poder polarizado, que, na linguagem de Hurrell, desafia a segurança direta de outros Estados devido à falta de um poder balanceado.

Não que este leve inexoravelmente a ameaças militares, é que o poder radicalmente não balanceado permite aos poderosos impor a lei aos menos poderosos, distorcer os termos da cooperação em seu próprio favor, impor seus próprios valores e modos de atuar e minar as regras das quais a cooperação estável e legítima inevitavelmente depende (HURRELL, 2009, p. 36).

De fato, a experiência dos processos históricos que a humanidade tem sobre o poder, sobretudo no contexto do dilema da segurança entre o ocidente e a extinta União 
Soviética, é que qualquer país poderoso tende a aumentar exageradamente o seu poder militar. Existe aqui aquilo que se pode considerar insaciabilidade pelo poder, tanto militar, como econômico, e de ditar as regras internacionais.

Mario Scerri apresenta uma questão fundamental nesta perspectiva, ao indagar se o fenômeno dos BRICS constitui ou assume a possibilidade de ruptura na evolução global do sistema de inovação ou se representa a emergência de nova variedade de capitalismo, com alto nível de estruturação dentro da ordem mundial existente. Tomando a escravatura e exemplificando apenas pelo Brasil, observa que este país, depois de ser colônia portuguesa, mal alcançou sua independência, passou a apoiar a colonização africana e escravizou brutalmente os negros. Quais são os parâmetros de balanceamento e legitimação do poder? A legitimidade das ações políticas e econômicas no mundo real depende exclusivamente dos que detêm o poder e não se define porque tais ações sejam justas e legítimas em si. Os teóricos do balanceamento brando defendem a maior preocupação pelo consenso e não imposição nas questões globais e relações econômicas que garantam a integração regional e global.

Para compreender melhor tal teoria de balanceamento brando, é importante analisar o pensamento de alguns acadêmicos chineses, ainda que não sejam adeptos de tal teoria, apresentado pelo conferencista Hao Qian. O recurso a tal pensamento baseia-se na noção do papel da China e seus homólogos na criação de consensos internacionais. $O$ argumento dos cépticos centra-se em duas perspectivas: existência de dilemas em ações coletivas e problemas sociais dentro dos Estados. Avançam ainda sobre a impossibilidade de construir um conhecimento comum tendo em conta as diferentes ideologias, sistemas econômicos, civilizações, localização geográfica, cultura e legados históricos. Estes autores citados por Qian argumentam que, dada a diversidades de fatores, as perspectivas de união e colaboração constituem uma fala vazia. Richard Haass, um intelectual céptico vinculado no Partido Republicano, é citado por Gonçalves (2010) fazendo uma profecia de um mundo caótico nos próximos anos. A base do seu vaticínio é a dificuldade de formar consensos para os próximos desafios. Estaria ele forçando a inferência de que um mundo liderado por uma potência é mais consensual do que quando orientado por várias? Que saudades o mundo tem das monarquias e do absolutismo? 0 cepticismo estaria desta forma não reconhecendo que a multipolaridade do poder é uma necessidade imperativa para o bem-estar da humanidade? Quais seriam os outros países a conduzir com maior protagonismo a nova ordem global senão os BRICS, dado que esse processo significa, sobretudo, autonomia financeira? Estas são as interrogações que os cépticos não respondem no texto de Qian.

61 Para Gonçalves (2010), Wallerstein (2002) e Dos Santos (1993), o imperialismo dos Estados Unidos, única superpotência do mundo, estatuto que gozou logo após o colapso da União Soviética, já não existe mais. Esta realidade é consequência tanto das escolhas feitas pelos próprios dirigentes norte-americanos, como das ações das demais potências. Gonçalves (2010, p. 144) admitem que "a correlação de forças entre os Estados na arena internacional se alterou irremediavelmente, em prejuízo dos norteamericanos. Houve, assim, o encurtamento da distância que separa os Estados Unidos de seus competidores e a configuração de nova estrutura do sistema internacional de poder".

62 Tomando como base de análise a concentração das atenções tanto em termos de debates políticos e acadêmicos, quanto em termos de evidências de desempenho econômico, industrial, relativos a centros de manufatura mundial, assim como das 
elevadas percentagens de PIB alocados à área militar, é fácil visualizar o maior protagonismo dos BRICS. Aliás, Fareed Zakaria, citado por Gonçalves (2010), chamou de "mundo pós-americano" o que constituiria a terceira grande mudança da era moderna ${ }^{11}$, por ele apelidada de "ascensão do resto" e referida pela PNUD por meio da expressão "ascensão do sul". É, para Zakaria, o resto que vai ascender ao poder e controlar todas as decisões internacionais. O termo "resto", ${ }^{12}$ assumido por Zakaria, ajuda a perceber que a diversidade cultural e as diferenças de modelos econômicos, políticos e sociais apresentados pelos cépticos como obstáculo, são, no mundo atual, uma oportunidade para a melhor reorganização do mundo. Um novo momento em que a participação na política e na produção econômica aparece mais distribuída por todos os continentes: Índia e China na Ásia, Rússia na Europa, Brasil na América e África do Sul em África, numa virada para dinamizar o comércio Sul-Sul, cujos indicadores apresentados pelo relatório da PNUD (2013) mostram um acentuado aumento das relações comerciais, quando comparado com as relações Norte-Norte ${ }^{13}$.

Scerri (2014), respondendo a sua questão sobre se os BRICS representavam a possibilidade de ruptura na evolução global do sistema de inovação ou se afiguram a emergência de nova variedade de capitalismo, com alto nível de estruturação dentro da ordem mundial existente, indica que os BRICS são uma associação independente. A iniciativa dos BRICS de criar um Novo Banco de Desenvolvimento e o Arranjo Contingente de Reservas para financiamento de infraestruturas dos países dos BRICS e dos países em desenvolvimento, assim como a criação e do Fundo Monetário dos BRICS, envolvem aportes financeiros relevantes. Cada uma das duas instituições financeiras conta com um aporte de 100 bilhões de dólares. Embora os memorandos da Cúpula dos BRICS de Fortaleza não apontem uma concorrência com as instituições da Bretton Woods, é de esperar que na atual situação de crise destas instituições se assista a um deslocamento dos credores para os BRICS, quebrando o tradicional monopólio do Banco Mundial e do FMI.

Retomando a questão de Scerri (2014) sobre se os BRICS representam ou não uma ruptura com a atual lógica capitalista, ele acredita na ruptura, mas esta acontece apenas dentro da estrutura da tradicional lógica capitalista. Brasil e a China, por exemplo, apresentam consideráveis experiências em termos de gestão de crescimento econômico dentro da estrutura dos requisitos do desenvolvimento humano para a transformação do Sistema Nacional de Inovação (SNI). O modelo chinês, de basear seu crescimento econômico em exportações, no contexto da lógica neoliberal, deverá ser partilhado dentro dos BRICS. Desta forma, Scerri (2014) aponta que é difícil falar de ruptura na atual evolução do capitalismo enraizado nos BRICS. Mesmo a China, que era uma economia centralizada e quase fechada em si mesma, para assinalar rápido crescimento precisou se abrir ao mundo. $\mathrm{O}$ mesmo acontece com a já liberalizada economia indiana e com as democráticas e neoliberais economias sul-africanas e russas.

Em contrapartida, Dos Santos (2012), respondendo à sua questão sobre que tipo de mudanças básicas o novo sistema mundial precisa, indica que a emergência de novos países industrializados na Ásia e América Latina alterou a hegemonia absoluta dos EUA, Europa e Japão. $O$ crescimento econômico dos países islâmicos, a integração dos países da América Latina e a conseqüente formação do Mercosul são fatores que desenham uma nova ordem mundial, mais complexa e difícil de administrar.

Para Dos Santos, os EUA continuarão hegemônicos por algum período, mas essa supremacia será subjugada pela UE, Japão e Rússia, assim como pela China, Brasil, Índia 
e África do Sul. O fim da administração Bush e a crise econômica a partir de 2007 marcam o fim da era da liderança norte-americana internacional. 0 autor continua indicando que o mundo assiste, na segunda década de 2000, a aceleração da globalização, que irá culminar com uma civilização planetária e uma partilha da liderança e objetivos globais. No novo mundo, "haverá muito pouco espaço para as pretensões de hegemonia absoluta, superioridades raciais ou étnicas, racionalização ideológica de experiências temporariamente bem sucedidas" (DOS SANTOS, 1993, p. 14). O motor destas profundas mudanças globais é a economia emergente polarizada, o que poderá permitir equilíbrios regionais. Aliás, o VI Fórum Acadêmico ou os Think Tanks dos BRICS defendeu que "o comportamento dos países dos BRICS na arena global não pode ser dissociado de suas políticas externas regionais". E a declaração de Fortaleza da VI Cúpula BRICS mostra que os BRICS não pretendem ser uma entidade à parte, mas sim, respeitam os laços diplomáticos previamente estabelecidos entre países e as decisões de organismos internacionais. A partir destas iniciativas, os BRICS poderão fortalecer todos os acordos que proporcionem compromisso com o direito internacional e com o multilateralismo, contribuindo para a paz mundial, estabilidade econômica, a inclusão social, a igualdade, o desenvolvimento sustentável e a cooperação mutuamente benéfica com todos os países.

Retomando o problema das diferenças políticas, culturais, históricas e sociais, Qian explicita o papel da diversidade na unidade e, a partir da observação empírica, delineou os vários organismos internacionais dos quais uma parte ou todos os R5 são membros. Todos os países dos BRICS são membros do G20. Da Organização da Cooperação de Shanghai (SCO) fazem parte a Rússia, a Índia e a África do Sul. De acordo com Hurrell (2009) existe ainda uma nova colisão de países do sul, liderada por Brasil e Índia na Organização Mundial de Comércio (OMC); e o fortalecimento de laços de relações entre Índia, Brasil e África do Sul no Fórum IBAS. Os objetivos centrais do IBAS, apontados por Lima e Hirst (2009), são a defesa de instituições e valores democráticos, outorgando um fundamento político ao fórum. Estes três países são potências regionais, ricos em recursos naturais e com níveis razoáveis de industrialização. Esta posição regional, em regiões em que predominam países pobres, e a ausência de políticas de gestão de imigração e das desigualdades no acesso a renda, pode converte-se em uma desvantagem. A questão não deve ser olhar os países pobres como problema, mas questionar-se sobre os fatores que condicionaram a premência dos fatores que mantém esses países pobres e agir sobre esses fatores. Um dos princípios dos BRICS deve ser exatamente declarar o fim da pobreza e das desigualdades entre os países em nível mundial. Este o grande desafio que se coloca aos BRICS, ou seja, reverter o cenário discriminatório e discriminador criado pelos EUA.

No século XX os EUA criaram instituições e estruturas multilaterais no imediato pós Segunda Guerra Mundial: a Organização das Nações Unidas (ONU), instituições financeiras internacionais, como Fundo Monetário Internacional (FMI), Banco Mundial (BM), Acordo Geral de Tarifas e Comércio (Gatt) e um denso sistema de alianças militares no Oceano Atlântico e Pacífico ${ }^{14}$. Este fato gerou um mundo com uma linha divisória entre ricos e pobres, regimes democráticos e monopartidários, terroristas,... no qual todos os que desafiam o poder dos EUA deviam ser abatidos e fragilizados. Os BRICS e todos os outros países têm, hoje, a nobre missão de reverter este cenário.

Hurrel (2009), contudo, apresenta uma questão fundamental sobre até que ponto os países dos BRICS não estão absorvidos por esta estratégia norte-americana? Sua opinião 
é que não há, na atual conjuntura, uma absorção desses países, porto que, como é de conhecimento geral estes países, principalmente a China e a Rússia, que por ter poder de veto no Conselho de Segurança da ONU, têm constituído uma "quebra cabeça" à pretensões imperialistas norte-americano.

O posicionamento de Gonçalves (2010), ao aplicar a expressão "ascensão do resto", não é oposição aos EUA ou anti-americanismo, como defendem Zakaria e outros, mas uma excelente visão de simples era pós-americanismo. No mundo atual, os Estados Unidos são uma nação entre outras que devem cooperar em pé de igualdade com outros Estados na busca de consensos sobre os problemas globais. Trata-se da morte das velhas teorias de Bush, de não querer perder tempo negociando com interlocutores fracos, para a emergência da era de ausência de fracos e fortes, nos assuntos que dizem respeito a todos. Mas a lógica das relações entre Estados não é uma lógica de amizades, mas sim de interesses. E em teoria política choques de interesses são susceptíveis a conflito. A partir destes pressupostos, fica ao ar o seguinte questionamento: como gerar consensos num espaço guiado por interesses e maior probabilidade de choques?

Sem dar resposta à questão anterior, o Professor da Shanghai International Studies University, Hao Qian defende uma era de cooperação internacional, na qual choques de interesses não devem significar intervenções militares. O rápido crescimento econômico dos BRICS, medido pelo PIB, chocou o mundo pelo seu único modelo de desenvolvimento cujas características são descritas por Qian nos seguintes termos:

centralizado + meio centralizado + livre mercado na China, atualmente conhecido por centro de manufactura mundial; um invisível autoritarismo de influência da economia Russa desenvolvida pelas exportações do seu gás natural; responsáveis e moderadas políticas monetárias e financeiras do Brasil; o socialismo do estilo indiano combinado com o mercado livre do estilo ocidental, conhecido pela indústria de tecnologia de informação e na África do Sul, o modelo dual de desenvolvimento sul-africano bastante apreciado a nível mundial (QIAN, 2014, p. 2).

Estes são, para o autor, as principais particularidades não liberais de modelos de desenvolvimento na era pós-neoliberal e por isso é, para muitos acadêmicos, momento ideal para que os BRICS liderem a nova ordem econômica mundial em construção. $O$ modelo, centralizado + meio centralizado + livre mercado na China, apresentado por Qian pode ser a forma de ultrapassar os desafios apontados pelo Professor Elmar Altvater. No seu ceticismo, Altvater acredita não existir condições para uma nova hegemonia financeira a partir dos BRICS porque estes países não têm uma moeda nacional com estatuto de moeda internacional, não têm poder de controlar a estabilidade da taxa de câmbio livre no mercado internacional, uma política fiscal e monetária autônoma e uma política monetária nacional e internacional com maior segurança contra choques externos. Embora os países dos BRICS tenham as maiores reservas no mundo, elas estão em dólares. Nem a China, país com maiores reservas mundiais, assim como a União Européia, cumprem os requisitos combinados de uma moeda nacional, mas que funciona como internacional com disponibilidade e segurança. Assegurar os direitos de propriedade privada, poder militar e cultura financeira equiparável da financeira do World Trade Centre. De fato, os BRICS podem não reunir todas estas condições apresentadas por Elmar, mas é preciso notar que o gradualismo sobre o qual caminham pode lhes levar a ter estas condições. Para além disso, o desenvolvimento econômico que estes países registram hoje não seguiu restritamente o modelo norte-americano. o caso da China, por exemplo, foi um capitalismo do estilo chinês (socialismo + capitalismo) que conduziu o desenvolvimento. 
Assim, teorias de seguir as mesmas pegadas devem ser abandonadas e respeitar as possibilidades de inovação de cada um dos países ou união de países.

\section{Cooperação Brasil e África do Sul}

73 A metodologia de Hao Qian sugere a análise daquilo que ele denomina duas asas dos BRICS, ou seja, Brasil e África do Sul. Começa por recordar que dentro dos R5 não existe um plano de cooperação geopolítica, sendo apenas o objetivo central destes países a cooperação econômica.

As relações políticas Brasil e África do Sul datam de $1947 / 48^{15}$ com abertura nos dois países de representações diplomáticas. Filho (2010) aponta como um dos elementos distintivos em nível social o apartheid sul-africano e democracia racial no Brasil. Avança ainda como obstáculo para relações comerciais vigorosas o paradoxo da diferença entre os dois países, sem vínculo histórico e cultural. As diferenças quanto ao racismo situam-se apenas no fato de a África do Sul ter legislado a segregação racial. Enquanto o caso brasileiro baseou-se na farsa ideologia de democracia racial. Não são as diferenças culturais e históricas que impediram um comércio vigoroso, mas o contexto político neste período desfavorável e os problemas tecnológicos capazes de flexibilizar de forma eficiente e eficaz tais relações. No seu artigo intitulado "Brasil e África do Sul: Relações em Nova Fase" Gonçalves (2010) enfatiza o desenvolvimento da tecnologia de transportes e das comunicações como impulsionadores da globalização e de novas relações comerciais entre os Estados.

75 Até anos 1950 os dois países perseguiam mais objetivos eminentemente políticos e estratégicos do que comerciais voltados para inserção internacional e, sobretudo, o incipiente desenvolvimento de tecnologia de transportes e comunicações como na maior parte dos países ainda pobres. A título de exemplo, Filho (2010) apresenta como obstáculo às relações comerciais entre Brasil e África do Sul em particular, e a África no geral, o apoio brasileiro ao colonialismo português no continente africano, que de forma decisiva ajudou a permanência deste regime até os anos 70. Mas o mais grave ainda foi a tomada de atitudes enganosas pela parte do Brasil no seu inconsistente discurso oficial. Ou melhor, um discurso oficial de apoio a autodeterminação africana, a independência, mas por outro lado, auxílio a Portugal na colonização e escravatura. Vale lembrar que o Brasil foi o último país em nível mundial a abolir a escravatura.

No contexto de estreitamento de relações entre Brasil e África do Sul, o ex-ministro das Relações Exteriores brasileiro, Luiz Felipe Lampreia, vendo-se na impossibilidade de uma cooperação com a Comunidade para o Desenvolvimento da África Austral (SADC sigla em inglês) e MERCOSUL, em 2000 "esteve na Cidade de Cabo para conversações com autoridades sul-africanas a respeito de um projeto de integração econômica, [...], como um dos três países prioritários para a política externa brasileira no continente" (Filho, 2010, p. 137). Apesar deste interesse brasileiro por um projeto de cooperação com a África do Sul, o país africano não colocou na lista dos países prioritários o Brasil, chegando a se ver numa contingência de atender inúmeros pedidos ${ }^{16}$. Não só a África do Sul não colocou o Brasil na lista das suas prioridades de cooperação econômica, como também, tem, à semelhança do Brasil dos anos 70, apresentado discursos contraditórios, o que foi classificado por Patrick Bond "falar pela esquerda e andar pela direita". 

internacionais (a luta pelo fim do protecionismo dos países desenvolvidos, isto é, liberalização do comércio internacional, os fluxos internacionais de capitais desregulados) torna os dois países aliados. Isto poderá, de acordo com Pio Penna Filho, criar um ambiente propício uma cooperação econômica virtuosa. Aqui se visualiza o otimismo de Hao Quian ao defender que tanto a África do Sul quanto Brasil estão estrategicamente situados nos oceanos Índico e Atlântico, respectivamente. Isso permite uma vasta diversidade de oportunidades tanto para navios de cargas, bem como para controle de armamento e pesca. Igualmente são países mais desenvolvidos nas suas respectivas regiões e ricos em recursos naturais. O Brasil na América Latina, o mais populoso e extenso país da região com uma longa costa, já começou a arrastar os seus vizinhos para participar nas cúpulas do BRICS, tal é o caso da VI Cúpula de Fortaleza. Espera-se que a África do Sul, uma superpotência da África Austral e do continente africano, possa também influenciar os países africanos a participar junto aos BRICS na instauração de uma NOM.

Dois aditivos são apresentados por Williams Gonçalves para facilitar a cooperação econômica internacional: o desenvolvimento das tecnologias de transportes e comunicações e a emergência de instituições internacionais que sejam governamentais, assim como, não-governamentais. Instituições com capacidade de negociar, sobretudo quando se trata de temas globais. Outro fator importante é a vigorosa consciência sobre a capacidade dos países emergentes reivindicarem a sua participação no processo decisório internacional.

\section{Cooperação Rússia, Índia e China}

Brasil e África do Sul foram considerados no modelo de Qian como as duas asas dos BRICS dada à sua localização geopolítica. As relações geopolíticas são fundamentais para catapultar a segurança entre os países. E a Rússia, Índia e China são os três pilares ou o corpo, ou ainda "BRICS plane", o que consubstancia o modelo de análise de Qian de "three pillars + two wings". As potencialidades destes países são várias: armas nucleares, extensão geográfica e liderança geopolítica russa nos países da Eurásia e indiana na região sul asiática em termos de desenvolvimento. As longínquas disputas de fronteira entre China e Índia, fortes pendências na região de Tibete, onde está o líder espiritual Dalai Lama, são apontadas pela literatura especializada como sendo um verdadeiro entrave dos ganhos mútuos entre China e Índia. A este respeito, Qiu Meirong uma pesquisadora dos assuntos das relações China-Índia, entrevistado pelo Professor Hao Quian, aponta que o único problema que perturba a cooperação entre China e Índia é o das fronteiras. Prossegue indicando que as disputas de fronteiras têm exacerbado a confiança mútua entre Beijing e Nova Delhi. China está envolvida ainda em disputas marítimas com os seus vizinhos do sul e que a Índia podia jogar um importante papel de mediador. 0 problema da disputa de fronteiras entre os dois países impede a cooperação diplomática em assuntos geopolíticos da região, na qual os dois países são os principais jogadores. Para esta pesquisadora, a colaboração dos dois em nível energético e organização da economia regional seria vantajosa para ambos e para a região. Outro problema levantado por alguns estudiosos aponta as diferenças dos regimes políticos, democracia indiana e mono-partidarismo chinês. Apesar destes desafios, os dois países se aperceberam que têm muito por cooperar em termos de 
manufatura, ciência de computação e importação de energia. Esta cooperação é tomada por Qian como fundamental para a segurança da região sul asiático.

Apesar de a China ser a grande economia no mercado mundial, apresenta várias indefinições não relativamente à poluição ambiental e conseqüente projeção sustentável, mas, sobretudo com os seus países vizinhos tais como: Japão, Filipinas, Correia do Sul e Malásia. E o problema da autonomia de Taiwan junto às Nações Unidas, tem gerado desconfortos com os EUA e a UE e, atualmente, a China assiste neste segundo semestre de 2014 manifestações populares em Hong Kong pela abertura democrática. Os EUA sempre fazem exercícios militares com os seus aliados regionais e ratificam acordos estratégicos militares, colocando a China numa situação de maior vulnerabilidade. A China enfrenta problemas internos, como por exemplo, uma escalada de corrupção, os tradicionais problemas de direitos humanos, desigualdades sociais, trabalho descartável, protestos e manifestações fabris, pobreza, entre outros.

Aliado ao caso Afeganistão, a China, a Índia e a Rússia se vêm na responsabilidade de cooperação geopolítica e estrategicamente para garantir paz e estabilidade política na Ásia meridional. Um terço da população mundial, a extensão territorial e a localização geoestratégica dos três países são tomadas por Qian (2014) e Guimarães (2010) como fatores dinamizadores da cooperação para desenvolvimento e segurança.

Atualmente a Rússia enfrenta a crise ucraniana junto ao alargamento da NATO e da União Européia (UE), mas recebe um suporte concreto e especial da China que tem direito de veto no Conselho de Segurança das Nações Unidas. A Rússia tem muito a dar aos BRICS, não só dado ao seu poder militar no seio destes países, mas, sobretudo, pelas suas experiências de enfrentamento à maior potência mundial e os massivos recursos energéticos - gás, metais raros, indústria de pesca e potenciais rotas marítimas. À semelhança da China, Rússia tem poder de veto no Conselho de Segurança das Nações Unidas e deseja o reforço dos BRICS na discussão de assuntos internacionais nas ONU. De acordo com Hao Qian o pensamento estratégico da Rússia, um país Ártico, é potenciar as rotas de navegação marítima, de tal forma que os passageiros do nordeste possam alterar a atual estratégia de segurança e os cinco países costeiros do Ártico e juntamente com outros não Árticos se unam nos problemas da região. Tais problemas incluem: desenvolvimento, preservação e proteção ambiental, aquecimento global, pesca de espécies raras. Pretende ainda balancear energias como gás, água e recursos minerais. A Rússia pretende liderar a governabilidade da região para ultrapassar ou minimizar alguns destes problemas, contudo, dada a falta de recursos, a China pode jogar um papel importante. Mas por outro lado, a China não é muito experiente na liderança de assuntos internacionais quanto a Rússia, que poderá prover modelos para se lidar com a diplomacia internacional. Realmente, a Rússia é um dos poucos países mundiais que historicamente vem se lidando com problemas internacionais mais complexos, desde questões ideológicas até às questões militares. Esta é, a nosso ver, uma das maiores contribuições que a Rússia pode oferecer a todos os países dos BRICS. Contudo, há autores que contestam essa supremacia, como Kagarlitsky (2005) que assevera uma certa debilidade dos líderes russos em matéria internacional. Uma debilidade na política internacional proporcional à economia e assuntos sociais internos. $\mathrm{O}$ autor continua indicando que "a Rússia não é uma potência global; não é nem se quer um ator auto-definido como menor (como Finlândia e Japão). É simplesmente um campo de batalha dos conflitos globais que estão surgindo, um objeto, mais que sujeito de relações internacionais" (Kagarlitsky, 2005, p. 305). Mas, 
essa visão mais pessimista de Kagarlitsky, nos parece, não tem em conta a mínima retrospectiva histórica para analisar o papel da URSS na bipolarização do mundo, o papel da URSS na vitoriosa Segunda Guerra Mundial e o atual poder de influenciar e, na medida de possível, alterar o rumo dos acontecimentos internacionais. Toda essa experiência militar, política e da diplomacia internacional, constitui uma herança da atual Rússia que continua enfrentando a superpotência norte-americana. Chomsky (2004), por exemplo, apresenta um panorama contrário ao apontado por Kagarlitsky, ao afirmar que a Rússia voltou a entrar na corrida armamentista depois de os EUA jogarem um papel no Tratado de Mísseis Anti-Balísticos (ABM). $O$ autor assevera que a Rússia se reposicionou aparentemente através da colocação de seus mísseis no que se chama "Lançamento e Advertência", uma receita para destruir o mundo. A China, que não é apenas um bom aluno a nível econômico, mas também militar, aprendeu a lição e está na corrida militar nuclear. A entrada da China nesta corrida, analisa Chomsky (2004), obriga a Índia e o Paquistão a fazê-lo também, o que conduz a uma cadeia que atingirá todo o Médio Oriente e grande parte do resto do mundo.

Kagarlitsky (2005) reconhece que a participação da Rússia na cúpula do Grupo dos sete países mais desenvolvidos (G-7), transformando-os de sete para oito (G-8), permitiu a Rússia ganhar igual estatuto formal e foi um êxito fundamental para a política externa. Independentemente dos pretextos norte-americanos, da Europa Ocidental e do Japão perseguidos, a entrada da Rússia não foi por acaso, mas pelo reconhecimento meritório do papel deste país nos assuntos internacionais, mesmo dentro de grandes perdas de vantagens competitivas em relação aos EUA. Claramente que a Rússia tem inúmeros problemas, como apoio a Bush à luta contra terrorismo. Muitos desses problemas podem ser enquadrados na estratégia de sobrevivência perante uma superpotência e aliados americanos.

Desde a Rússia imperial à Rússia Estado, este país está condenado a lidar com assuntos bastante delicados. Sua decisiva participação vitoriosa nas duas Guerras Mundiais, cujos aliados constituíram, "a faca de dois gumes" (provérbio popular), desde a ideológica Guerra Fria, passando pela guerra no Vietnã, na Correia até a guerra na Síria, Geórgia, Ucrânia, Tchetchênia, entre outras que lhe permitiu ganhar experiências em assuntos internacionais. Ideológica no sentido de que não se tratou de confrontação militar, dado que tanto a Rússia quanto os EUA estavam fortemente armados, com centenas de mísseis nucleares. $\mathrm{O}$ significado da confrontação militar seria o fim dos dois estados e quiçá do mundo. Tratava-se da luta pela implementação em todo o mundo de modelos políticos e econômicos. A Rússia defendia o sistema socialista baseada numa economia centralmente planificada e partido único (o Partido Comunista), igualdade social, mas sem democracia e os EUA defendiam sistema econômico capitalista, assente no mercado livre, na propriedade privada e sistema democrático. O problema não era a implementação interna destes modelos, mas a corrida aos aliados, outros países no contexto da experiência a Segunda Guerra Mundial. A Organização do Tratado Atlântico Norte (OTAN) em 1949 para os EUA e o Pacto de Varsóvia para a União Soviética, cuja defesa era a militarização dos países socialistas, as vantagens geopolíticas e energéticas são, entre vários fatores, o que fazem da Federação Russa uma grande potência na diplomacia internacional e nos assuntos políticos militares, apesar de todas as dificuldades.

Embora a China não seja um profissional calejado em assuntos internacionais quanto a Rússia, como afirma Qian (2014), o país pode jogar um importante papel na mediação da 
crise ucraniana. China tem jogado um papel decisivo na tenaz relação entre os EUA, UE, ONU e a Correia do Norte, como mediador. Uma China com menores recortes de envolvimento em guerras mundiais, como é o caso dos EUA, Grã-Bretanha, França, Rússia e outros países com expressão mundial, é para este artigo um dos países cujo discurso será de paz e harmonia global.

86 A Índia, China e Rússia apresentam enormes potencialidades culturais, econômicas e políticas, mas quando se fala das questões militares e da segurança regional, todos eles apresentam algumas fragilidades, quando analisados isoladamente. No contexto regional, o Afeganistão ${ }^{17}$, a crise ucraniana, as relações políticas da China com os seus vizinhos, que chegam a afetar a política externa chinesa junto aos EUA e a EU, são fatores que os BRICS como união deviam mediar na perspectiva de construir um mundo de consensos. Para o caso afegão os três países compreendem que a solução deste conflito significa estabilidade da Ásia central, sendo assim, Rússia, China e Índia sentem-se na responsabilidade de tornar esta região pacífica.

O professor Qian não analisa as potencialidades dos países dos BRICS apenas numa perspectiva isolada, ele sugere que tal vigor deve ser no contexto das já criadas relações comerciais fortificados pelo continente africano, pela Europa do Leste, pela América Latina e pela Ásia do Leste e Sul. Para ele, o tempo para colaboração entre os países, regiões e continentes está maturado e confia na maior significância das relações geopolíticas dos BRICS.

Alguns acadêmicos russos entrevistados pelo Professor Qian sobre quem deve ser o líder dos BRICS, asseguram que a China deve sê-lo considerando as maiores reservas de moeda internacional da China e o maior mercado econômico mundial. Os BRICS têm conjuntamente $40 \%$ de reservas internacionais e a China responde por $3 / 4$ desse montante. A participação da China na reserva de contingências dos BRICS foi de 41 bilhões de dólares contra 18,18, 18 e 5 bilhões da Rússia, Brasil, índia e África do Sul, respectivamente ${ }^{18}$. Contrariamente a isto, os acadêmicos chineses, também entrevistados pelo Professor Quian, pensam que uma vez que a China lidera no campo econômico, os outros países deviam liderar a organização em termos estratégicos. A fórmula adotada pela VI Cúpula dos BRICS em Fortaleza foi a distribuição de poderes e responsabilidade. Por exemplo, enquanto a China ganha o poder de sediar o Banco dos BRICS na China, Xangai, o primeiro presidente do Conselho de Governadores será da Rússia; o presidente do Conselho de Administração do Brasil; e o primeiro Centro Regional Africano será estabelecido na África do Sul.

Analisando a colaboração entre China e Brasil, Hao Qian aponta que os primeiros imigrantes chineses ao Brasil chegaram em 1812, com planos de produção de chá, algodão, exploração de minérios, construção de linhas férreas. Mais tarde chineses de Taiwan e Hong Kong visitaram o Brasil em busca de oportunidades comerciais. As relações diplomáticas em nível governamental iniciaram em 1974 e a China reconhece que Brasil joga um papel importante na América Latina, em termos da extensão territorial, populacional, econômicos e o seu modelo de desenvolvimento. O Brasil possui potenciais, recursos minerais e, na era pós-liberalismo conseguiu influenciar os países da região. A partir de políticas incrementais consegue quebrar as teorias neoliberais e entra em políticas de ajustamento estrutural e continua a perseguir a liberalização do comércio. Os dois países cooperam nos fóruns do G20, dos BRICS e na área da indústria, comércio e educação. 
90 Em síntese, todos os países dos BRICS quando analisados isoladamente apresentam vários problemas, sejam eles de ordem política, militares, sociais, econômicos, culturais e até mesmo de relacionamentos entre eles e com os seus vizinhos regionais e globais. Todavia, quando analisados conjuntamente, todos apresentam potencialidades invejáveis. O desafio atual é de acordo com Chellaney (2014), estabelecer e institucionalizar a cooperação entre os países membros e procurar formas de desenvolver relações, não só econômicas, mas também, geopolíticas. Esta visão de Chellaney foi cumprida nos acordos e memorandos de entendimento assinados na VI Cúpula de Fortaleza.

91 A cooperação e confiança política e militar mútua entre os BRICS, foi discutido na VI Conselho dos Thinks Tanks dos BRICS no Rio - 2014, como um dos focos mais problemáticos. Analisando os acordos da VI Cúpula dos BRICS de Fortaleza, nota-se que de fato entre os BRICS ainda não existe confiança mútua nestas duas áreas (política e militar). Todavia, o agendamento da reunião de Altos Representantes responsáveis por Segurança Nacional dos BRICS é um excelente passo para iniciativas de debates sérios em nível de cooperação política e militar. A proposta de Qian (2014) de cooperação política e militar entre os BRICS inclui a participação de outros países, como Israel, no caso asiático.

Na América Latina, Qian aponta como países estratégicos de alianças militares, o vulnerável México (em relação aos EUA, mas uma potencia regional no Caribe), a Venezuela e a Argentina. A política anti-americana venezuelana, pelo menos no Governo de Hugo Chávez, parece legitimar a inclusão de Venezuela nas alianças com os BRICS.

93 O primeiro ministro chinês, LI Keqiang visitou países africanos como Etiópia, Nigéria, Angola e Quênia, não para buscar alianças político-militares, mas para estreitar relações diplomáticas com a China. Contudo, para Qian tanto os países visitados, assim como outros, sejam eles desenvolvidos ou subdesenvolvidos, não devem ser ignorados pelos BRICS na fortificação de alianças políticas, econômicas e militares. Apesar de todos os problemas que o Zimbábue atravessa, o Governo de Robert Mugabe tem sido crítico às políticas neoliberais norte-americanas e da Grã-Bretanha, o que lhe torna uma potência com a qual os BRICS deviam contar. Para além do Zimbábue, da Coréia do Norte, do Irã, do Egito, da Cuba, da Indonésia, da Tailândia e outros países de África, da América Latina, da Europa do Leste e da Ásia, todos podem jogar um importante papel para contrabalançar o militarismo norte-americano e instaurar uma nova ordem mundial. Não se trata aqui de defender ideias anti-americanas, mas reconhecer que o mundo já está polarizado militarmente e os países que ainda não o fizeram, devem o fazer. Não para legitimar guerras, mas para conduzir com segurança o processo de desenvolvimento econômico e construção de um mundo de consenso nos assuntos internacionais.

Cepik (2009) ao estudar a capacidade militar da África do Sul, conclui que em nível regional esta é ótima, e faz deste país uma grande potência continental. No entanto, sua cooperação econômica com os outros membros dos BRICS poderá transcender este horizonte para níveis político-militares e aí a capacidade sul-africana é exageradamente diminuta. Porém, quando analisada no nível dos IBAS ela é competitiva, com a melhor relação equipamento/pessoal. Tem uma indústria própria de blindados e artilharia com uma boa posição mundial. A situação do Brasil, não é má, apesar de relativa obsolescência, porque "possui quase cinco reservistas para cada 
afetivo na ativa e mais de um terço de pessoal ativo serve da marinha e da Aeronáutica. O problema do Brasil, [...] não é tanto a sua distribuição, mas qualidade e nível de prontidão estratégica, [...] com menor treinamento [...]" (CEPIK, 2009, p. 100-101). Das três componentes que Marco Cepik considera fundamentais no estudo das questões militares (componente terrestre das Forças Armadas, Naval e Aéreo) a marinha de guerra indiana é excepcional nos IBAS e a mais poderosa no sul da Ásia, embora com fragilidade logística e de reposição de peças e munições. Não obstante o poderio terrestre, a força sul-africana é menor em nível naval, mas com alta tecnologia de produção doméstica. A Marinha brasileira enfrenta o mesmo problema de obsolescência e com tremendas dificuldades mesmo para travar uma guerra regional. Em termos do componente aéreo das Forças Armadas, a Índia apresenta consideráveis vantagens, capaz de intentar uma guerra com o Paquistão, seu tradicional rival e quiçá com a China, outro concorrente. À semelhança da África do Sul, o Brasil desenvolve em nível nacional, aviões de combate, cujo processo ocorre entre os dois países. Esta "psedoconcreticidade", ou seja, fragilidades e potencialidades nesta e naquela área, político-militar e econômico, só pode ser superada através da cooperação em todos os horizontes entre os países dos BRICS. A união faz a força, diz o velho ditado popular. Embora dados político-militares da China e Rússia não tenham sido analisados neste texto, os altos investimentos destes dois países na área da defesa, asseguram uma possível liderança militar em longo prazo.

Com uma análise que nos parece reducionista, ou seja, de que os aspectos militares já foram ultrapassados, Chellaney (2014) mostra que atualmente os BRICS têm estudado formas moderadas e cautelosas de resolver os problemas da Síria, da Ucrânia e do Irã sem precisar de intervenção militar do Ocidente. Os BRICS devem basear suas ações nos valores máximos da lei internacional, pautados por uma atitude inclusiva de todos os países do sul. Aliás, para além da novidade da ascensão do sul ou do "resto", o sul é apresentado por Lima e Hirst (2009) como aquele que apresenta algumas características peculiares: i) forte componente idealista, cujo enfoque era introduzir mudanças na economia política internacional, questionando a vigência de uma ordem econômica liberal, considerando injusto o tratamento de desigual como igual; ii) heterogeneidade econômica e política do sul, criando problemas de coordenação coletiva.

Esta atitude mais a esquerda do sul contra um sistema da economia política internacional que simplesmente distribui miséria e guerras, deve ser fortalecida e promovida. Esta é uma das maiores responsabilidades que se apresenta aos BRICS.

\section{Considerações Finais}

97 Com o objetivo de analisar as oportunidades e possibilidades para uma nova ordem mundial através dos BRICS, face à dualidade de crises dos EUA (econômica e política junto aos aliados), foi produzido o presente artigo. Embora, sob ponto de vista histórico, o poder hegemônico da Grã-Bretanha tenha declinado a favor dos Estados Unidos da América logo após a Grande Depressão dos anos 30 e a Segunda Guerra Mundial, e embora tal fato não autorize uma dedução lógica de que a atual crise dos EUA é uma crise que resultara em uma transição a favor dos BRICS, dado que não é a crise o fator que move a necessidade da transição e muito menos o próprio processo transitório, pelo contrário, ela é prejudicial ao ritmo de crescimento econômico dos mercados emergentes. Todavia, a dificuldade superação e da crise, que se inicia nos anos 70 e 
continua sem perspectiva de conclusão ainda hoje, não nos impede de aceitar que a hegemonia norte-americana está em queda em função das transformações históricas, políticas e econômicas globais que o mundo vem conhecendo desde os anos 90 .

o fim do socialismo e do comunismo e a celebrada vitória do capitalismo e da democracia simbolizada pela queda do muro de Berlim geraram uma série de estudos cujas conclusões apontam para algo contrário à ideia essencial da celebração. Esses estudos mostravam que não se tratava de vitória de um sistema ideológico sobre o outro, mas do início de uma nova fase histórica. Os horrores incríveis de guerras que haviam abalado a humanidade até os anos 80 ganharam certo alívio e a esperança e o desejo por um mundo melhor se anunciou Todavia, o comportamento militarista dos EUA, junto aos aliados, e da Rússia, desde a guerra no Vietnam, na Coréia, na Tchetchênia, na Geórgia, no Kuwait, no Iraque e na Líbia aumentavam a aflição pelo mundo melhor e, consequentemente, reduziu as esperanças. Os estudiosos da economia política internacional iam acompanhando par e passo o comportamento da economia mundial que ia gerando focos de desenvolvimento, criando blocos econômicos regionais e relações econômicas fortes. Este fato, naquele momento, renovou as esperanças sobre futuro melhor.

A criação, em 2001, do termo BRICS pelo Grupo Econômico Goldman Sachs e a oficialização das relações em 2009 entre os países dos BRICS abriu espaço não apenas para alargar os debates acadêmicos em busca de soluções políticas para uma nova ordem mundial, mas, sobretudo, gerou duas coisas fundamentais. Em primeiro lugar, a perspectiva econômica de união entre os países dos BRICS transbordou a linha divisória entre o econômico e o político, e, em segundo lugar, os BRICS aparecem como interlocutores legítimos para implementar os pensamentos acadêmicos e políticos sobre a forma como a nova ordem deveria ser implantada. São na verdade uma entidade válida não só pelo seu expressivo poder econômico, mas, sobretudo, por constituírem o único ponto de equilíbrio entre os dois mundos, o mundo pobre e o mundo rico. Adicionalmente, o poder de veto da China e da Rússia e a sua reconhecida participação no Conselho de Segurança das Nações Unidas, na Organização Mundial de Comércio, entre outros organismos internacionais, em defesa da paz, do fim dos embargos e integração econômica de todos os países atribuem maiores responsabilidades para aos BRICS na instauração de uma nova ordem mundial.

No campo literário a análise do papel dos BRICS na instauração de uma nova ordem mundial para além de vasta e profunda, ela não é consensual. Ela é caracterizada por dois pensamentos antagônicos predominantes: i) os BRICS vão efetivamente restaurar uma nova ordem mundial, e; ii) os BRICS não vão instaurar uma nova ordem mundial. Quatro argumentos são apontados pelos cépticos para justificar a impossibilidade de uma nova ordem mundial: i) os EUA continuam a deter o poder militar, econômico e científico-tecnológico; ii) as diferenças culturais, históricas, políticas e sociais no seio dos BRICS não permitem desenvolver relações de dimensão planetária; iii) a crise norteamericana não é tão profunda que possa justificar uma crise transição. Este artigo assume que os fatores que conduzem a Nova Ordem Mundial (NOM) não estão associados apenas aos EUA ou aos BRICS, mas a mudanças estruturais como conseqüência da ditadura política dos EUA o que gerou a formação de aliados fracos que se fortificam na união, no contexto das integrações regionais. Em segundo lugar, o enfoque de amizades econômicas ultrapassa em larga medida o militarismo, embora os investimentos militares possam continuar nos próximos anos, dado ao dilema da 
segurança e a busca de equilíbrio, entre estes países em particular com os EUA e todos os outros países do mundo. Quanto à diferenças no seio dos BRICS, a globalização já provou pela criação de um mundo planetário e não se conhece nenhuma experiência que forjou a união dos povos. Exatamente a complementaridade ocorre no diferente e por isso, o argumento das diferenças culturais, sociais, econômicas, históricas e políticas que não foi capaz de travar a globalização não são suficientes para fundamentar o fracasso dos BRICS e do mundo excluído.

101 Os otimistas, por sua vez, sustentam seus argumentos no inédito crescimento dos BRICS, em particular, e do Sul, em geral. A localização geográfica dos BRICS, sobretudo do Brasil e da África do Sul, é apontada como uma vantagem geopolítica que, no contexto da onda de integração regional, poderá permitir arrastar maior apoio dos países regionais. Se, por um lado, a experiência político-militar e diplomática, em particular da Rússia, herdada no contexto da URSS, em se lidar com assuntos complexos da economia política internacional é um fator decisivo para a nova ordem, por outro lado, a capacidade chinesa em lidar com a tensão junto aos seus vizinhos e com os EUA, a espetacular capacidade de gestão de políticas econômicas junto à Índia são fatores importantes que, ao lado do terceiro mundo, conduzem a NOM.

A criação, na VI Cúpula dos BRICS, que ocorreu na Fortaleza, em junho de 2014, do Novo Banco de Desenvolvimento dos BRICS e do Fundo Monetário dos BRICS, mostra a implementação de iniciativas que poderão substituir o monopólio financeiro das instituições de Bretton Woods. A presença na Cúpula de Fortaleza de 33 países da Comunidade de Estados Latino-americanos e Caribenhos mostra uma nobre iniciativa de envolvimento dos países do terceiro mundo, esperando-se que nas próximas reuniões os países africanos, asiáticos e da Europa do Leste possam também ser convidados, mesmo como observadores. Embora reconhecendo que a união dos BRICS é essencialmente econômica, a participação dos países é importante para garantir consensos em relação ao futuro.

\section{BIBLIOGRAFIA}

ALTVATER, Elmar. A Crise Econômica Internacional e o "Desenvolvimento Sustentável” Brasil e América Latina. In: DVD: O Socialismo do século XXI. PPFH/UERJ, Aula 9, Rio de Janeiro, 2012.

ANDERSON, Perry. A Batalha das Idéias na Construção de Alternativas. IN: BORON, Atilio. A.(Org.). Nova Hegemonia Mundial: Alternativas de mudanças e movimentos sociais, CLACSO, $1^{\text {a }}$ edição, Buenos Aires, 2004.

BANDEIRA, Luiz Alberto Moniz, Dimensão Estratégica e Política Externa dos Estados Unidos. In: Ministério das Relações Exteriores, III Conferência Nacional de Política Externa e Política Internacional - III CNPEPI - "O Brasil no mundo que vem aî": Estados Unidos, Editora: Fundação Alexandre de Gusmão, Brasília, 2008.

BOND, Patrick. O Império Norte-Americano e o Subimperialismo Sul-Africano. In: PANITCH, Leo e LEYS, Colin. O Império Realoaded, Editora Marlin Press CLACSO, São Paulo, 2005. 
BORON, A. A. Império e Imperialismo: Uma Leitura Crítica de Michael Hardt e Antonio Negri, $1^{\mathrm{a}}$ edição, Bueno Aires: Clacso, Tradução de: Lilian Koifman, 2002.

BRICS. Joint Statistical Publications, Fortaleza. Disponível em: http://www.brics.ibge.gov.br/ downloads/BRICS_Joint_Statistical_Publication_2014.pdf, Acedido em 10/10/2014. . Joint Statistical Publications, Durban - South Africa. Dispunível em: http:// www.statssa.gov.za/news_archive/Docs/ FINAL_BRICS\%20PUBLICATION_PRINT_23\%20MARCH\%202013_Reworked.pdf, Acedido em $10 / 10 / 2014$

Treaty for the Establishment os a BRICS Contingent Reserve Arrangement. Disponível em: http://brics6.itamaraty.gov.br/agreements, acedido em 10/10/2014.

CARNOY, Martin. Estado e Teoria Política. Tradução Puccamp, 2ª edição, Campinas: Papirus, 1988. CHOMSKY, Noam. Os Dilemas da Dominação. IN: BORON, Atilio. A.(Org.). Nova Hegemonia Mundial: Alternativas de mudanças e movimentos sociais, CLACSO, 1ª̣ edição, Buenos Aires, 2004.

CEPIK, Marcos. Segurança nacional e cooperação Sul-Sul: Índia, África do Sul e Brasil. IN: LIMA, M. R. e HIRST, M. (Org.). Brasil, Índia e África do Sul: Desafios e Oportunidades para Novas Parcerias. Editora Paz e Terra, São Paulo, 2009.

DOS SANTOS, Theotôneo. Do Terror à Esperança: Auge e declíneo do neoliberalismo, Editora Idéias \& Letras, São Paulo, 2004.

. Crises Económicas e Ondas Longas na Economia Mundial, Rio de Janeiro, 2002. . Economia Mundial: Integração Regional e Desenvolvimento Sustentável. As novas tendências da economia mundial e integração da latino-americana, $4^{a}$ edição, Editoras Vozes, Rio de Janeiro, 1993. . What Kind of Basic Changes do We Need in the New Worl System? Some Reflections on Globalization, Development and Social Justice. IN: QUIJANO A. et al. Latin American Critical Thought: Teory and Practice, CLACSO Editor, Buens Aires, 2012.

. Verdades e Mitos sobre a Invasão do Iraque. IN: PANITCH, L. e LEYS, C. (Ed.). O Novo Desafio Imperial, Socialist Register, CLACSO, São Paulo, 2004.

CHELLANEY, Brahma. Geopolitical opportunities and challenges for BICS, Índia, 2014.

FILHO, Pio Penna. Brasil e África do Sul - Perspectiva Histórica. In: ZHEBIT, Alexander et all. Brasil - Índia - África do Sul: Emergência do Sul Global, Editora Gramma, Rio de Janeiro, 2010.

FUKUYAMA, Francis. O Fim da História e o Último Homem, Rio de Janeiro, Rocco, 1992.

GAIDAR, Yegor. A crise financeira e a Rússia. In: VELLOSO, João Paulo dos Reis et al. A Crise Global e o Novo papel Mundial dos BRICS, Editora: José Olympio, Rio de Janeiro, 2009.

GONÇALVES, Williams. Brasil e África do Sul: Relações em Nova Fase. In: ZHEBIT, Alexander et al. Brasil - Índia - África do Sul: Emergência do Sul Global, Editora Gramma, Rio de Janeiro, 2010.

GOLDMAN SUCHAS GLOBAL ECONOMICS GRUP. BRICs and Beyond. Austrália, 2007.

GUIMARÃES, Lytton Leite. Índia: Política Externa e Segurança: Do Idealismo à Realpolitik.

In: ZHEBIT, Alexander et all. Brasil - Índia - África do Sul: Emergência do Sul Global, Editora Gramma, Rio de Janeiro, 2010.

HARVEY, D. O Neoliberalismo: História e Implicações. Edições Loyola, Tradução: Adail Sobral e Maria Stela Gonçalves, $4^{\mathrm{a}}$ edição, São Paulo, 2013. 
. O Enigma do Capital e as Crises do Capitalismo, Tradução: João Alexandre Peschanski, Boitempo Editora, 1ª Edição, São Paulo, 2011. . O "novo" imperialismo: acumulação por espoliação. In: PANITCH

Leo e LEYS, Colin (Ed.). O Novo Desafio imperial, Socialist Register, CLACSO Livros, 2004.

HELLER, Hermann. Teoria do Estado, Tradução: Lycurgo Gomes da Motta, Editora Mestre Jou, São Paulo, 1968.

HIRSCHMAN, Albert. Será o fim da Guerra Fria um desatre para o "Terceiro Mundo"? IN: DUPLAS, Gilberto; LAFER, Celso e DA SILVA, Carlos Eduardo Lins (Org.). A Nova Configuração Mundial do Poder, Editora Paz e Terra S.A, São Paulo, 2008.

HOBSBAWM, Eric. Era dos Extremos: O Breve Século 1914 - 1991, Tradução: Marcos Santarrita, 2a Edição, São Paulo, 1995.

HURRELL, Andrew. Hegemonia, Liberalismo e ordem global: qual é o espaço para potências emergentes? In: Os BRICS e a Ordem Global, Editora FGV, Rio de Janeiro, 2009.

JACKSON, Robert e SORENSEN, Georg. Introdução às Relações Internacionais. Tradução: Bárbara Duarte, Jorge Zahar Editor, Rio de Janeiro, 2007.

KAGARLITSKY, B. O Estado Russo na Era do Império Norte-Americano. In: PANITCH

Leo e LEYS, Colin. O Império Realoaded, Editora Marlin Press CLACSO, São Paulo, 2005.

KLARE, Michael. Sangue por petróleo: a estratégia energética de Bush e Cheney. In: PANITCH Leo e LEYS, Colin (Ed.). O Novo Desafio imperial, Socialist Register, CLACSO Livros, 2004.

KREGEL, Jan. A crise global e as implicações para os países emergentes: o B de BRICS se justifica? In: VELLOSO, João Paulo dos Reis et al. A Crise Global e o Novo papel Mundial dos BRICS, Editora: José Olympio, Rio de Janeiro, 2009.

LIMA, M. R. e HIRST, M. A iniciativa IBAS e a Cooperação Sul-Sul: desafios intelectuais e possibilidades políticas. IN: LIMA, M. R. e HIRST, M. (Org.). Brasil, Índia e África do Sul: Desafios e Oportunidades para Novas Parcerias. Editora Paz e Terra, São Paulo, 2009.

LUFT, Lya. Crise - a dimensão humana. In: VELLOSO, João Paulo dos Reis et al. A Crise Global e o Novo papel Mundial dos BRICS, Editora: José Olympio, Rio de Janeiro, 2009.

MACFARLANE, Neil. O “R” dos BRICS: A Rússia é uma potência emergente? In: HURRELL, Andrew. Os BRICS e a Ordem Global, Editora FGV, Rio de Janeiro, 2009.

MAQUIAVEL, Nicolau. O Príncipe. Tradução: Maria Flavia dos Reis Amambahy, $1^{a}$ edição, Editora Ideia Jurídica, Rio de Janeiro, 2014.

MARX, Karl e ENGELS, Friedrich. Manifesto do Partido Comunista, Global editora, $6^{\mathrm{a}}$ edição, São Paulo, 1987.

. O Capital: Crítica da Economia e Política, vol. 1, Livro 1, 31ª edição, Tradução: Reginaldo Sant'Anna, Civilização Brasileira editora, Rio de Janeiro, 2013. . O Capital: Crítica da Economia e Política, vol. 4, Livro 3, 3a edição, Tradução: Reginaldo Sant'Anna, Civilização Brasileira editora, Rio de Janeiro, 2013. . 0 Capital: Crítica da Economia e Política, vol. 2, Livro 2, 2ª edição, Editado por Friedrich Engels, Tradução: Regis Barbosa e Flávio R. Kothe, São Paulo, 1985.

NOGUEIRA, João Pontes e MESSARI, Nizar. Teorias das Relações Internacionais: Correntes e 
Debates, Elsevier Editora, Rio de Janeiro, 2005.

PALMARES, Gilberto. Dilma Rousseff, na abertura do debate de Alto Nível da 69ª Assembléia Geral da ONU. Jornal Inverta, Rio de Janeiro, Edição de 27/09/2014.

PANITCH, L. e GINDIN, S. Capitalismo Global e Império Norte-Americano. IN: PANITCH, L. e LEYS, C. (Ed.). O Novo Desafio Imperial, Socialist Register, CLACSO, São Paulo, 2004.

Programa das Nações Unidas para Desenvolvimento (PNUD). Relatório de Desenvolvimento Humano de 2013. A Ascensão do Sul: Progresso Humano num Mundo Diversificado. New York, 2013.

QIAN, Hao. Where is BRICS heading for? Chinese Scholars Perspective, China, 2014.

SADER, Emir. A Nova Toupeira: O Caminho da Esquerda Latino Americano, Boitempo Editora, $1^{1 \mathrm{a}}$ Edição, São Paulo, 2009.

SCERRI, Mario. Modes of Innovation and the BRICS National System of Innovation. Brasil, 2014.

TREIN, F. Unipolaridade e Multipolaridade: Novas Estruturas na Geopolítica Internacional e os BRICS. IN: VIANA A. R.; BARROS S. P. e CALISXTRE A. B. (Org.). Governação Global e Integração da América do Sul, Ipea, Brasília, 2011.

United States of America, Council of Economic Advisers. Economic Report of the President. Washington, 2014.

WALLERSTEIN, Immanuel. Após o Liberalismo: Em busca da reconstrução do mundo, Editora Vozes, Tradução: Ricardo Anibal Rosenbusch, Rio de Janeiro, 2002.

\section{NOTAS}

1. O termo foi inicialmente criado como um acrônimo - BRIC - diretamente relacionado ao nome dos países emergentes Brasil, Rússia, Índia e China, cujo agrupamento efetivo, na forma de uma associação informal, foi oficializado em 2006. Desde a criação do termo, tais países, como conjunto, passaram a ser referidos como "os BRICs", a letra s minúscula apenas designando a passagem do termo para o plural. Com a agregação da África do Sul, em 2011, a letra S, em maiúsculo, relacionada à grafia em língua inglesa do nome desse país (South Africa), foi incorporada ao termo, cuja grafia passa a ser BRICS.

2. Como exposto anteriormente, a literatura conceitual sobre a sigla BRICS toma a associação das letras iniciais dos cinco países (Brasil, Rússia, Índia, China e África do Sul) para designar os mercados econômicos emergentes. Todavia, tal nomenclatura varia de autor para autor. Lima e Hirst (2009), por exemplo, lançam uma infinidade de termos para definir esses países, como, por exemplo, potências médias; países intermediários; potências regionais e emergentes. Esses termos pretendem, na verdade, expressar algo de econômico que diferencia esses países dos demais.

3. Território que se estende entre Europa e Ásia, especificamente situado entre Ásia Central e Mar Cáspio, abrangendo de acordo com Bandeira (2008) Cazaquistão, Armênia, Azerbaijão, Quirguistão, Tajiquistão, Turquemenistão, Sibéria Ocidental e parte setentrional do Paquistão, e é circundada pelo Afeganistão, Rússia, China, Índia e Irão.

4. O Tratado do Atlântico Norte, deu origem à OTAN (NATO), assinado em Washington, DC em abril de 1949, e composto inicialmente por doze países, que são: Estados Unidos da América, Bélgica Canadá, Dinamarca, França, Islândia, Itália, Portugal, Reino Unido, Luxemburgo, Noruega, Países Baixos. Mais tarde aderiram países como Bulgária, Alemanha, Eslováquia, Eslovênia, Hungria, Grécia, Estônia, Espanha, Turquia, Romênia, Letônia, Lituânia, Polônia e República Checa. 
5. Cuja posição mundial em termos de PIB era no período de 2001 a 2008, de acordo com Gonçalves (2010): China, Rússia, Brasil, Índia e África do sul $3^{\circ}, 8^{\circ}, 10^{\circ}, 12^{\circ}$ e $32^{\circ}$ lugares, respectivamente.

6. A questão da substituição do dólar como moeda internacional é um dos indicadores de análise, ao lado do poderio militar e alienação da língua inglesa como língua internacional sob poderio americano. Ou melhor, a entrada dos BRICS como decisores e impositores da nova ordem mundial depende da instauração de substitutos, em parte, destes três elementos: a moeda internacional, o poder militar de dimensão global e a língua.

7. Sigla cunhada por Chellaney (2014) em função das letras iniciais das moedas dos cinco países dos BRICS (Real, Ruble, Rupee, Renminbi e Rand).

8. De acordo com Bond (2005), três navios de guerra norte-americanos foram abastecidos na África do Sul e a fábrica estatal de armamento Danel vendeu material bélico ao exército britânico. 9. Há que sublinhar que não são todos os Estados que se associam aos Estados Unidos. Cuba, Irã e Correia do Norte, entre outros, afirmam-se anti-americanos no discurso e na prática, ainda que via sanções internacionais sejam obrigados a ter um certo comportamento.

10. A noção de países emergentes aplicada neste texto inspira-se no texto de Neil MacFarlane (2009). Das várias características citadas pela autora, interessam para este estudo duas: preponderância regional e aspiração a um papel global e um posicionamento de contestação à hegemonia dos Estados Unidos. Para este debate, esse posicionamento deve internacionalmente ser declarado e demonstrado. A Rússia sempre fez isto, e é por isso que não é no artigo de Neil tomado como país emergente.

11. A primeira mudança da era moderna foi, para Fareed Zakaria, citado por Gonçalves (2010), a ascensão do mundo ocidental no início do século XV até século XVIII. Seu resultado foi a modernidade. A segunda mudança foi a ascensão dos EUA, que se tornou a principal grande potência. A partir dos finais do século XIX, seu saldo foi se transformar na mais industrializada nação jamais vista. O início do século XXI é da "ascensão do resto".

12. Resto, para Zakaria, são os diferentes indivíduos e grupos dispersos e, acrescente-se, "diversificados em termos culturais, modelos econômicos e políticos...".

13. A PNUD entende, por relações comerciais Norte-Norte, as relações entre Austrália, Canadá, Japão, Nova Zelândia, Estados Unidos e a Europa Ocidental.

14. As bases americanas estão em todo o mundo como é o caso da: USPACOM, USNORTHCOM, USSOUTHCOM, USCENTCOM, USEUCOM E USPACOM. Estas bases estão estrategicamente localizadas em locais onde existem potências capazes de desafiar Washington, na África, por exemplo, único continente no mundo sem armas nucleares embora haja alianças americanas com alguns países, não chegam a constituir bases militares.

15. Mas o consulado brasileiro na Cidade de Cabo foi criado em 1918.

16. As preferências sul-africanas são: EUA, União Européia, Japão e China e outros como Líbia, Irão, Indonésia e Cuba (Ibidem). A questão dos direitos humanos apesar de ser um tema bastante candente nos debates literários e que todos os países se afirmam ser defensores dos direitos humanos precisa de uma análise séria. O Brasil, por exemplo, com a sua política de combate ao crime nas favelas parece engendrar uma eliminação efetiva das populações pobres. Muitos países com minoria exageradamente opulenta ou riquíssima contra a maioria pobre devem ser qualificados como países contra os direitos humanos dado que milhares de pessoas morrem de fome enquanto as minorias ricas estão abarrotadas de comida que até resta para cães. Ou melhor, os cães dos ricos vivem melhores, uma vida digna e de abundância do que pobres.

17. O Professor Qian cita a reunião de Fevereiro de 2013 na qual a Rússia, China e Índia discutiram o problema da paz para o Afeganistão em particular e a região central asiática em geral.

18. Cf. o Tratado de estabelecimento de reserva de contingências dos BRICS, disponível em: http://brics6.itamaraty.gov.br/agreements. 


\section{RESUMOS}

A necessidade de uma nova ordem mundial não é projeto específico dos BRICS como maiores mercados econômicos emergentes. Sua gênese está ancorada na celebrada vitória do capitalismo e democracia norte-americanos sobre o socialismo e comunismo da URSS em 1990. Todavia, os BRICS aparecem como interlocutor imprescindível para conduzir, sob ponto de vista prático, ações concretas na implementação da nova ordem mundial. A dualidade de crises norteamericana - a política, junto aos tradicionais aliados, cuja explicitação foi expressiva a partir de 2003, com a invasão ao Iraque; e a econômica, a partir de 2007 - constitui uma oportunidade, ainda que não suficiente em sim mesma, para mudanças radicais na ordem mundial. 0 inédito crescimento econômico dos BRICS, em particular, e do sul, em geral, aparece como possibilidades para conduzir o processo de instauração de novas relações de consenso na economia política internacional.

The necessity of a new world order is not a BRICS's specific project in the present market's conjuncture; its origin is in the celebrated victory of capitalism and of American democracy on the USSR's communism in the Nineties. Nevertheless, the BRICS seem to be a necessary interlocutor for the implementation of a new world order. Their inedited economic growth in the Global South seems to signify the possibility of establish new consensus-based relations in international economic politics.

Le besoin d'un nouvel ordre mondial n'est pas un projet exclusif des BRIC's en tant que marché économique émergent le plus important. Sa genèse est appuyée sur la victoire célébrée du capitalisme et de la démocratie nord-américaine par rapport au communisme de l'URSS et de ses satellites dans les années quatre-vingt-dix. Néanmoins, les BRICS se présentent comme l'interlocuteur essentiel capable de mettre en œuvre des actions concrètes vers le nouvel ordre mondial. Son inédit accroissement économique en particulier et au Sud en général sont des possibilités d'établissement de nouveaux rapports consensuelles dans l'économie politique internationale.

La necesidad de una nueva orden mundial no es un proyecto específico de BRICS como mayores mercados emergentes económica. Su Génesis está anclado en la célebre victoria del capitalismo y la democracia norte-americanos sobre el socialismo y el comunismo en la URSS en 1990. Sin embargo, los BRICS aparecen como interlocutor indispensable para la conducción, bajo el punto de vista práctico, acciones concretas en la implementación de la nueva orden mundial. La dualidad de la crisis americana - política, junto a los aliados tradicionales, cuya explicación fue expresiva desde 2003, con la invasión de Irak; y la económica, desde 2007 - es una oportunidad, aunque no es suficiente en sí misma, para cambios radicales en la orden mundial. El crecimiento económico sin precedentes de los BRICS, en particular y del sur aparece generalmente como posibilidades de liderar el proceso de establecer nuevas relaciones de consenso en economía política internacional. 


\section{ÍNDICE}

Palabras claves: BRICS, globalización, nueva orden mundial, nueva política económica, Estados Unidos

Mots-clés: BRICS, mondialisation, nouvelle ordre mondiale, économie politique internationale, États-Unis d'Amérique

Palavras-chave: BRICS, globalização, nova ordem mundial, nova política econômica, USA

Keywords: BRICS, globalization, new world order, new political economy, USA

\section{AUTOR}

\section{NELSON LAURA MABUCANHANE}

Professor no Instituto Superior de Administração Pública - ISAP - Moçambique. Doutorando da Universidade do Estado do Rio de Janeiro (UERJ), Programa de Pós-Graduação em Políticas Públicas e Formação Humana (PPFH), na linha Estado e Políticas Públicas. Mestrado em Políticas Públicas pela Universidade de Pequim - China e Licenciado em Ciências Religiosas pela Pontifícia Universidade Urbaniana de Roma, através do Instituto Superior "Maria Mãe de África" de Moçambique. Endereço eletrônico: nelsonisap@gmail.com. 